\title{
Meteorology during the DOMINO campaign and its connection with trace gases and aerosols
}

\author{
J. A. Adame ${ }^{1}$, M. Martínez ${ }^{2}$, M. Sorribas ${ }^{3}$, P. J. Hidalgo ${ }^{4}$, H. Harder ${ }^{2}$, J.-M. Diesch ${ }^{5}$, F. Drewnick ${ }^{5}$, W. Song ${ }^{2}$, \\ J. Williams ${ }^{2}$, V. Sinha ${ }^{2,6}$, M. A. Hernández-Ceballos ${ }^{7, *}$, J. Vilà-Guerau de Arellano ${ }^{8}$, R. Sander ${ }^{2}$, Z. Hosaynali-Beygi ${ }^{2}$, \\ H. Fischer ${ }^{2}$, J. Lelieveld ${ }^{2}$, and B. De la Morena ${ }^{1}$ \\ ${ }^{1}$ Atmospheric Sounding Station - El Arenosillo, Atmospheric Research and Instrumentation Branch, National Institute for \\ Aerospace Technology, Huelva, Spain \\ ${ }^{2}$ Atmospheric Chemistry Department, Max Planck Institute for Chemistry, Mainz, Germany \\ ${ }^{3}$ Andalusian Center for Environmental Research (CEAMA), University of Granada, Granada, Spain \\ ${ }^{4}$ University of Huelva, Department of Environmental Biology, 21071, Huelva, Spain \\ ${ }^{5}$ Particle Chemistry Department, Max Planck Institute for Chemistry, Mainz, Germany \\ ${ }^{6}$ Indian Institute of Science Education and Research, Mohali Sector 81, S. A. S. Nagar, Manauli PO, 140306, Punjab, India \\ ${ }^{7}$ University of Huelva, Applied Physic Department, 21071, Huelva, Spain \\ ${ }^{8}$ Wageningen University, Meteorology and Air Quality, Wageningen, the Netherlands \\ * currently working at: European Commission, Joint Research Centre, Institute for Transuranium Elements, Nuclear Security \\ Unit, Ispra, Italy
}

Correspondence to: J. A. Adame (adamecj@inta.es)

Received: 30 April 2013 - Published in Atmos. Chem. Phys. Discuss.: 22 July 2013

Revised: 18 January 2014 - Accepted: 23 January 2014 - Published: 5 March 2014

\begin{abstract}
The DOMINO (Diel Oxidant Mechanisms in relation to Nitrogen Oxides) campaign was carried out from 21 November to 8 December 2008 at the El Arenosillo station (SW of Spain) in a coastal-rural environment. The main weather conditions are analysed using local meteorological variables, meteorological soundings and synoptic maps, as well as back trajectories of the air masses using the HYSPLIT (Hybrid Single-Particle Lagrangian Integrated Trajectory Model) model and a high spatial resolution of meteorological fields. Measurements of the main meteorological parameters were collected both from the surface and from a tall tower. A detailed land use analysis was performed on a $80 \mathrm{~km}$ scale showing the main types of vegetation and land use. Also the main anthropogenic atmospheric emission sources both industrial-urban from Huelva and from the urban Seville area - are shown. A study to identify air mass origins and their variation with height was carried out. In this intensive campaign, air masses coming from different areas with different emission sources were observed: from the NW, with a highly industrial-urban character; continental flows from northerly directions; from the NE, with a pathway starting
\end{abstract}

over the Seville metropolitan area and then continuing over the Doñana National Park; and maritime air masses coming from the Atlantic Ocean. To study the chemistry in the four atmospheric scenarios identified, gas -phase measurements of primary and secondary species such as ozone, NO, $\mathrm{NO}_{2}$ and $\mathrm{SO}_{2}$, biogenic and anthropogenic VOCs (volatile organic compounds) like benzene and isoprene, as well as total particle concentration and chemical composition of the aerosols are compared and discussed. The highest levels for total particle concentration, $\mathrm{NO}, \mathrm{NO}_{2}, \mathrm{SO}_{2}$, benzene, $\mathrm{PM}_{10}$, $\mathrm{PM}_{2.5}$ and chemical elements such as $\mathrm{As}$ or $\mathrm{Cu}$ were found under flows associated with industrial-urban emissions from the Huelva-Portugal sector which are transported to the site before significant removal by chemical or deposition mechanism can occur. The air masses from the north were affected mainly by crustal elements and biogenic sources, the latter being exemplified by the biogenic species such as isoprene, particularly in the first part of the campaign. The urban air from the Seville area, before arriving at El Arenosillo, traversed the Doñana National Park and therefore was affected by industrial-urban and biogenic emissions. This aged air 
parcel can transport low levels of $\mathrm{NO}_{\mathrm{x}}$, total particle concentration and $\mathrm{SO}_{2}$ as well as ozone and isoprene. Marine air masses from the Atlantic Ocean influence El Arenosillo frequently. Under these conditions, the lowest levels of almost all the species - with the exception of ozone levels associated to long-range transport - were measured.

\section{Introduction}

Regional atmospheric physics and chemistry over a region can be characterized through measurements either routinely carried out at atmospheric observatories or sporadically carried out within the frame of intensive measurement campaigns. The latter typically involve a larger number of specialized instruments, deployed together at the surface or on aircraft measuring many atmospheric parameters simultaneously (Geyer et al., 2003; Molina et al., 2010; Royer et al., 2011), sometimes at remote sites where permanent measuring systems do not exist and would be difficult to set up (Martinez et al., 2010; Williams et al., 2011). Atmospheric observatories, on the other hand, have the advantage of producing long-time data series which are needed for the characterization of seasonal dependencies and detection of long-term trends in air quality and even climate studies (Toledano et al., 2007; Cristofanelli et al., 2009; Sorribas et al., 2011).

El Arenosillo, located in the south-west of Europe, is an observatory with various atmospheric instrumentations measuring total ozone, ultraviolet radiation, surface gases (ozone and $\mathrm{NO}_{\mathrm{x}}$ ) and aerosols, among other factors. Due to the different atmospheric emission sources (biogenic and anthropogenic) surrounding this site and the orography features of this region, levels of atmospheric chemical species depend strongly on the air mass origin.

The diversity of source regions impacting the site, in addition to photochemical activity even in wintertime, together with the permanent instrumentation and long-time databases available at this observatory, made El Arenosillo the site of choice for the DOMINO campaign. DOMINO (Diel Oxidant Mechanisms in relation to Nitrogen Oxides) aimed to close the radical budget in a variety of air masses, and to study the processing of anthropogenic pollution in an environment with both anthropogenic and biogenic VOCs (volatile organic compounds). Many atmospheric variables were measured during the campaign, including meteorological variables (measured at the surface and at different altitudes from a tower and also using balloon soundings), trace gases (NO, $\mathrm{NO}_{2}, \mathrm{O}_{3}, \mathrm{SO}_{2}, \mathrm{~N}_{2} \mathrm{O}_{5}, \mathrm{HONO}$, VOCs, etc.), including radicals $\left(\mathrm{OH}, \mathrm{HO}_{2}, \mathrm{RO}_{2}, \mathrm{NO}_{3}\right)$, and aerosols (particle concentration, chemical composition, particle size distribution, etc.).

The database generated in the campaign has been used by several studies so far. A study in order to identify HONO sources has been performed by Sörgel et al. (2011); nighttime mixing ratios of boundary layer $\mathrm{N}_{2} \mathrm{O}_{5}$ and $\mathrm{NO}_{3}$ life- times depending on the type of air masses have been studied by Crowley et al. (2011); a general overview of the VOCs measured in the campaign, both biogenic (such as monoterpenes and isoprenes) and anthropogenic (such as benzene or toluene) has been published by Song et al. (2011); aerosol number and mass, polycyclic aromatic hydrocarbons and black carbon concentrations, among others, have been analysed by Diesch et al. (2012); OH reactivity as well as ozone production rates and regimes have been determined by Sinha et al. (2012); a study devoted to investigating the interactions between atmospheric boundary layer (ABL) dynamics and atmospheric chemistry using a mixed-layer model coupled to chemical reaction schemes has been performed by van Stratum et al. (2012).

The aim of this paper is to carry out a detailed analysis of the weather conditions during the campaign and to identify distinct air mass characteristics (urban, industrial and natural with continental and marine influences), in order to determine the meteorological conditions associated with these regimes and investigate their influence on the behaviour of $\mathrm{O}_{3}, \mathrm{NO}, \mathrm{NO}_{2}, \mathrm{SO}_{2}$ and $\mathrm{OH}$ reactivity; on isoprene and benzene particles; and on aerosol chemical composition. Therefore, this work's aims are complementary and an extension of the studies started by Diesch et al. (2012), Sinha et al. (2012) and van Stratum et al. (2012). The studies by Diesch et al. (2012) and by Sinha et al. (2012) both include analysis of air mass trajectories in order to distinguish observations in air masses from different sources. In this work we focus on a very detailed meteorological study in order to separate observations into four distinct source regions, discarding all data which could not unambiguously be attributed to one of the defined source regions. Though in general there is reasonable agreement with these prior studies, we do derive a somewhat different distribution.

A review of the emissions sources in this region and instrumentation is presented in Sect. 2. A method for classification of the air masses is presented in Sect. 3.1 and applied to the data from the campaign together with a detailed analysis of land use around the site. Section 3.2 is devoted to an overview of the meteorological conditions considered as a whole and as a function of the air flow type. The levels and variations of the chemical species are presented in Sect. 3.3. The results are discussed in Sect. 4.

\section{Campaign framework, area description, emission sources, instrumentation and data}

\subsection{Campaign framework and area description}

The DOMINO (Diel Oxidant Mechanisms in relation to Nitrogen Oxides) campaign was promoted by the Max Plank Institute for Chemistry in Mainz, Germany (MPICH) and performed in cooperation between the MPICH and the National Institute for Aerospace Technology (INTA). The 


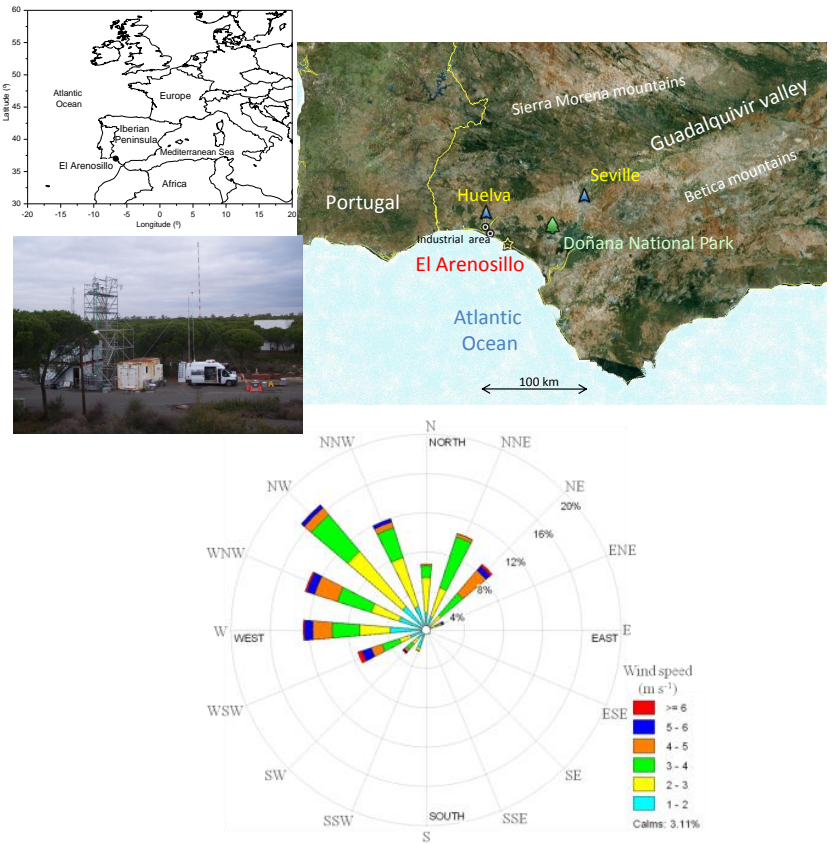

Fig. 1. Clockwise, from upper left: location of El Arenosillo in Europe; sites on the coast and in the Guadalquivir valley; wind rose for the measurement period; and the infrastructure installed for DOMINO campaign.

measurements took place at El Arenosillo $(37.1 \mathrm{~N}, 6.7 \mathrm{~W}$, 40 m a.s.l.) from 21 November to 8 December 2008.

At the atmospheric sounding station El Arenosillo (ESAt), several atmospheric parameters are monitored routinely. Measurements of the atmospheric total ozone column at this site started in 1980, surface meteorology in 1994, ultraviolet radiation in 1997 (Antón et al., 2012), total aerosol in 2000 (Toledano et al., 2007), surface ozone in 2000 (Adame et al., 2010a, b), aerosol size distribution in 2004 (Sorribas et al., 2011), aerosol scattering and back-scattering coefficients in 2006, surface $\mathrm{NO}$ and $\mathrm{NO}_{2}$ in 2007 (Notario et al., 2013) and aerosol absorption coefficient in 2012.

El Arenosillo is located in the Doñana National Park in the south-west of the Iberian Peninsula, close to the Atlantic coastline (Fig. 1). The nearest town is Mazagón, $9 \mathrm{~km}$ towards the WNW, with a population of $\sim 4000$. The city of Huelva, with a population of 150 thousand (INE, 2009), is situated $26 \mathrm{~km}$ to the NW. Close to Huelva city there are three industrial complexes with chemical and petrochemical activities.

To the SSW of El Arenosillo is the Atlantic Ocean, which is the origin of frequent maritime air masses which are channelled inland from the Gulf of Cádiz through the Guadalquivir valley. Air masses originating in the Sahara also occasionally arrive from this direction, though not during the period of the campaign. Along the coast there is continuous maritime traffic of ships travelling to or from the port of Huelva.
Seville metropolitan area is $75 \mathrm{~km}$ to the NE from the coastline of El Arenosillo; with a population of more than 1.5 million, it is the most densely populated urban area in the south of the Iberian Peninsula. In addition to important traffic emissions, there also are some atmospheric emissions from industrial factories; these are commented in detail in the next section.

The emissions from the industrial activities in Huelva affect the DOMINO site when the wind blows from the WNWNNW sector. In November and December this situation occurs with an occurrence fraction between 5 and $10 \%$, similar to the annual mean of 4-10\% obtained from the historical series of 1994-2007. On the other hand, emissions from the area of Seville can also affect El Arenosillo when the wind comes from the NE-ESE sector, which occurs between 20 and $25 \%$ of the time during the November-December months and with a $10 \%$ occurrence annually.

\subsection{Emission sources}

The measurement area is regularly influenced by emission sources both of biogenic and anthropogenic origin. Due to its location in the Doñana National Park and the low traffic and population in the area during winter, there were no important anthropogenic emission sources in the direct vicinity of the measurement site other than occasional traffic on the road passing the site and the traffic to and from El Arenosillo. The closest relevant anthropogenic emission sources that can affect the measurement site are located in the Huelva and Seville cities.

According to the Andalusian Government inventory (CMAJA, 2005), total $\mathrm{NO}_{\mathrm{x}}$ emissions from Seville are 30631 tons $\mathrm{yr}^{-1}, 1.7$ times higher than from Huelva. The $\mathrm{NO}_{\mathrm{x}}$ emissions in the province of Huelva associated with the vehicle traffic account for only $30 \%$ and industrial activities account for $48 \%$. In the province of Seville the vehicle traffic contribution is comparatively larger, reaching $53 \%$, while industrial emissions cause a mere $16 \%$. Total $\mathrm{SO}_{2}$ emissions from Huelva are 15983 tons $\mathrm{yr}^{-1}$, compared to 4511 tons $\mathrm{yr}^{-1}$ from Seville. $\mathrm{SO}_{2}$ emissions in Huelva are $96 \%$ industrial, mainly from the chemical and petrochemical sectors, while in Seville $55 \%$ of the $\mathrm{SO}_{2}$ emissions are related to the industry and $29 \%$ are from other activities. The $\mathrm{PM}_{10}$ emitted by traffic accounts for $14.7 \%$ in Huelva while industry emits $48 \%$ of a total of 2537 tons $\mathrm{yr}^{-1}$. In Seville the traffic is the most important $\mathrm{PM}_{10}$ source, contributing $25 \%$, and agricultural activities come second, contributing $20 \%$, of a total 5062 tons $\mathrm{yr}^{-1}$. Benzene emissions are larger in Huelva than in Seville, contributing $115{\text { tons } \mathrm{yr}^{-1} \mathrm{com}-}^{-}$ pared to 17 tons $\mathrm{yr}^{-1}$. In Huelva $84 \%$ of benzene is emitted by the petrochemical industries. VOCs (non-methane volatile organic compounds) are mainly (74\%) from biogenic origin in Huelva, while the industry emits $10.3 \%$ and traffic $2.5 \%$. In Seville biogenic emissions also are the main source of 
VOCs, with $31.5 \%$ from natural emissions and $23.5 \%$ from agriculture.

\subsection{Instrumentation and data}

The atmospheric sounding station (ESAt) is located less than $1000 \mathrm{~m}$ from the coastline, and hosts the atmospheric monitoring instrumentation continuously deployed by this observatory. Most of the instrumentation deployed for the DOMINO campaign, however, was placed at a site in between the ESAt and the coast, at about $100 \mathrm{~m}$ from the coastline, although several of the ESAt's instruments remained in the ESAt. The equipment at the main measurement site was distributed in four containers and the sampling inlets were installed on top of a $10 \mathrm{~m}$ high structure (see image in Fig. 1). Table 1 summarizes the main features of the instrumentation.

Ozone measurements were based on the absorption of ultraviolet radiation by ozone at $254 \mathrm{~nm}$. The ozone analyser, using a flow rate of $2 \mathrm{~L} \mathrm{~min}^{-1}$, was checked daily and calibrated before and after the campaign. The uncertainty and the detection limit were $1 \mathrm{ppb}$.

$\mathrm{NO}_{\mathrm{x}}$ data was collected with a high resolution and high sensitivity chemiluminescence detector (ECO PHYSICS CLD 790 SR, ECO PHYSICS, Dürnten, Switzerland) which carries out simultaneous in situ measurements of NO and $\mathrm{NO}_{2}$. A detailed description of the instrument, the calibration techniques and the error calculation has been given by Hosaynali Beygi et al. (2011). $\mathrm{SO}_{2}$ was monitored using an airpointer (Recordum $\mathrm{GmbH}$ ) with a detection limit of $1 \mathrm{ppb}$, which was calibrated periodically during the campaign.

An online sampling TD-GC-MSD (thermal desorptiongas chromatography-mass spectrometry) measurement system was used for the in situ observation of benzene and isoprene. Ambient air was drawn continuously through a main sample line at about $10 \mathrm{~L} \mathrm{~min}^{-1}$ by a high-volume pump. The residence time of air in the inlet line was approximately $12 \mathrm{~s}$.

$\mathrm{OH}$ reactivity was measured using the comparative reactivity method which employs an in situ competitive kinetics experiment in which a proton transfer reaction mass spectrometer (PTR-MS) is coupled to a turbulent flow glass reactor (Sinha et al., 2008, 2009, 2010).

Total concentration for particles larger than $2.5 \mathrm{~nm}$ was measured by an ultrafine condensation particle counter (UCPC) (TSI model 3776) operating at high flow and with a 1 min time resolution. The accuracy of the system is about $10 \%$. A description of the sampling system to transport the sampled aerosol into the UCPC can be found in Sorribas et al. (2011). Simultaneous $\mathrm{PM}_{10}$ and $\mathrm{PM}_{2.5}$ concentrations were sampled using two high-volume captors (CAVFPM1025, $30 \mathrm{~m}^{3} \mathrm{~h}^{-1}$ ), equipped with MCV $\mathrm{PM}_{10}$ and $\mathrm{PM}_{2.5}$ inlets and quartz micro-fibre filters. The time resolution was one filter every day with a sampling duration of $24 \mathrm{~h}$. Filters were weighed before and after sampling.
Local weather conditions were measured using a commercial instrument, Vaisala 520WXT. Temperature, relative humidity, pressure, rainfall, wind speed and direction data were collected. This sensor was used both on top of the structure and on a $100 \mathrm{~m}$ tower between the DOMINO measurement site and the ESAt building. To measure ultraviolet radiation, a Brewer MkIII spectroradiometer was used which has been monitoring this parameter from the roof of the ESAt since 1997.

Meteorological soundings were performed at the main DOMINO measurement site. Normally, two balloons were launched per day: one in the morning (around 10:0011:00 UTC) and one in the afternoon (around 16:00 17:00 UTC). On selected intensive days, however, a sonde was launched every hour. Meteorological data were obtained with GRAW DFM-06 radiosondes which measured temperature, relative humidity, and location (differential GPS). The measurement accuracy for temperature is $<0.2^{\circ} \mathrm{C}$ at a resolution of $0.1^{\circ} \mathrm{C}$. Relative humidity is measured with an accuracy of $<5 \%$ and a resolution of $1 \%$. Through the change in GPS position, wind speed $\left(<0.2 \mathrm{~m} \mathrm{~s}^{-1}\right.$ accuracy), wind direction, and updraft were calculated. Using surface pressure as additional input, the vertical profile of pressure $(<1 \mathrm{hPa}$ accuracy) was obtained.

$\mathrm{NO}, \mathrm{NO}_{2}$, isoprene, benzene, $\mathrm{OH}$ reactivity and the meteorological parameters were measured from the top of the mentioned structure; $\mathrm{O}_{3}$ and $\mathrm{SO}_{2}$ were measured in a mobile laboratory (Drewnick et al., 2012) with the inlet at the same height as those on the structure; and meteorological soundings were launched at the main DOMINO measurement site. Total particles, aerosol chemical and the ultraviolet radiation data were collected at the ESAt building. Finally, the $100 \mathrm{~m}$ tower was used to measure meteorological variables at the $50 \mathrm{~m}$ level. All the data were recorded with a time resolution of $10 \mathrm{~min}$ or less with the exception of the VOCs, which had a sampling time of $60 \mathrm{~min}$.

\section{Results}

\subsection{Air masses study}

\subsubsection{HYSPLIT model}

The trajectories followed by the air masses before reaching El Arenosillo were calculated using the HYSPLIT (Hybrid Single-Particle Lagrangian Integrated Trajectory) model, developed by the NOAA (National Oceanic and Atmospheric Administration) Air Resources Laboratory (ARL) (Draxler and Rolph, 2011). Several studies have been carried out at El Arenosillo in the past to study air masses in this region, including an analysis of $5 \mathrm{yr}$ of daily back trajectories and their relation to the aerosol optical properties (Toledano et al., 2007), 2 yr of six back trajectories per day and their relation with the sub-micron particle size distribution (Sorribas 
Table 1. The measurements made during the DOMINO campaign are tabulated alongside, parameter, time resolution, detection limit, responsible institute and location of the inlet.

\begin{tabular}{|c|c|c|c|c|c|}
\hline Measurement & $\begin{array}{r}\text { Time } \\
\text { resolution }\end{array}$ & $\begin{array}{r}\text { Detection } \\
\text { limit }\end{array}$ & $\begin{array}{l}\text { Technique or } \\
\text { Instrument }\end{array}$ & Institution & $\begin{array}{l}\text { Inlet } \\
\text { location }\end{array}$ \\
\hline $\mathrm{O}_{3}$ & $10 \mathrm{~m}$ & $1 \mathrm{ppb}$ & UV & INTA & Structure $(10 \mathrm{~m})$ \\
\hline $\mathrm{NO}, \mathrm{NO}_{2}$ & $10 \mathrm{~m}$ & $1 \mathrm{ppb}$ & CLD & MPI & Structure $(10 \mathrm{~m})$ \\
\hline $\mathrm{SO}_{2}$ & $10 \mathrm{~m}$ & $1 \mathrm{ppb}$ & Airpointer & MPI & Structure $(10 \mathrm{~m})$ \\
\hline Benzene & $60 \mathrm{~m}$ & $1 \mathrm{ppt}$ & TD-GC-MSD & MPI & Structure $(10 \mathrm{~m})$ \\
\hline Isoprene & $60 \mathrm{~m}$ & $1 \mathrm{ppt}$ & TD-GC-MSD & MPI & Structure $(10 \mathrm{~m})$ \\
\hline OH reactivity & $1 \mathrm{~m}$ & $3 s^{-1}$ & Reactivity (PTR-MS) & MPI & Structure $(10 \mathrm{~m})$ \\
\hline Particle number concentration & $1 \mathrm{~m}$ & $\begin{array}{r}0.01 \\
\operatorname{par} \mathrm{cm}^{-3}\end{array}$ & $\mathrm{UCPC}$ & INTA & ESAt \\
\hline $\mathrm{PM}_{10}-\mathrm{PM}_{2.5}$ & $24 \mathrm{~h}$ & & CAVF & INTA & ESAt \\
\hline UV radiation & $10 \mathrm{~m}$ & & Brewer MkIII & INTA & ESAt \\
\hline Surface meteo & $1 \mathrm{~m}$ & & Vaisala 520WXT & INTA & Structure $(10 \mathrm{~m})$ \\
\hline Surface tower & $1 \mathrm{~m}$ & & Vaisala 520WXT & INTA & Tower $(100 \mathrm{~m})$ \\
\hline Meteorological soundings & & & GRAW-DFM06 & MPI & Structure $(10 \mathrm{~m})$ \\
\hline
\end{tabular}

et al., 2011) and a study using $10 \mathrm{yr}$ of back trajectories to identify clusters of trajectories as well as their seasonal variation and dependence on altitude and on various features of the local meteorology (Hernández-Ceballos et al., 2013).

These studies are based on back trajectories computed once per day with a previous pathway of $120 \mathrm{~h}$, using input meteorological files with a horizontal resolution of $1^{\circ} \times 1^{\circ}$. In the framework of the DOMINO campaign, air mass trajectories have been calculated using HYSPLIT and meteorological fields of low resolution. Diesch et al. (2012) calculated back trajectories at $10 \mathrm{~m}$ arrival height every $2 \mathrm{~h}$ during the whole campaign period; Sinha et al. (2012) computed back trajectories at 20, 100 and 500 m; in van Stratum et al. (2012), the forward trajectories for a specific day at 100 and $2000 \mathrm{~m}$ were shown.

In this work a new and detailed back trajectory analysis with a higher resolution (both temporal and spatial) has been performed. The input meteorological files used in this study were the ERA Interim from the global model ECMWF (European Centre for Medium-Range Weather Forecasts). The files downloaded from ECMWF and converted to a format compatible with HYSPLIT have a spatial resolution of $0.25^{\circ} \times 0.25^{\circ}$ (approximately $27 \mathrm{~km}$ ), 16 vertical levels from surface to $500 \mathrm{mb}$ and $6 \mathrm{~h}$ of temporal resolution. 3-D kinematic back trajectories have been calculated using the vertical wind component given by the ERA Interim meteorological fields. $48 \mathrm{~h}$ back trajectories from El Arenosillo station have been simulated to analyse the origin and pathway of air masses. Hourly back trajectories were computed for the whole period of DOMINO, approximately 445 back trajectories at each altitude.

\subsubsection{Land use and definition of sectors}

Land use analysis has been demonstrated to be a powerful tool to understand the contribution of human activities as well as biogenic sources when interpreting local measurements of an atmospheric parameter (Williams et al., 2011). Potential local and regional influences on measurements during the campaign were assessed within an $80 \mathrm{~km}$ radius of the site using the Corine land cover database. These data were edited using the ArcGis $10\left(\right.$ Esri $\left.^{\odot}\right)$ Geographic Information Systems (GIS) software. The radius was chosen in order to include the city of Seville, which is the most populated area in the surroundings of the sampling site.

As described in Sect. 2.1, there are two significant urban centres, Huelva and Seville, within $80 \mathrm{~km}$ of the sampling site. Most anthropogenic emissions are assumed to come from these areas with their urban and industrial areas and transportation networks (in black in Fig. 2). Apart from those urban areas, other characteristic land uses will be described on the basis of the different back trajectories defined by the HYSPLIT model.

According to the different land uses in the surroundings of the measurement site, four different sectors can be defined that influence the measurement area with distinct anthropogenic and biogenic emissions. The sector between $\mathrm{W}$ and NNW, affected mainly by emissions from urban and industrial activities of Huelva, is referred to as the HuelvaPortugal sector. From the north, between NNW and NE, arrived air masses from the central Iberian Peninsula, containing mostly rural emissions and possibly also aged pollution from distant urban sources. This sector is identified as the continental-north sector. The sectors defined in this work as Continental-North, marine and Seville present a good agreement with the classification shown in Diesch et al. (2012). However, the Huelva-Portugal sector from this 


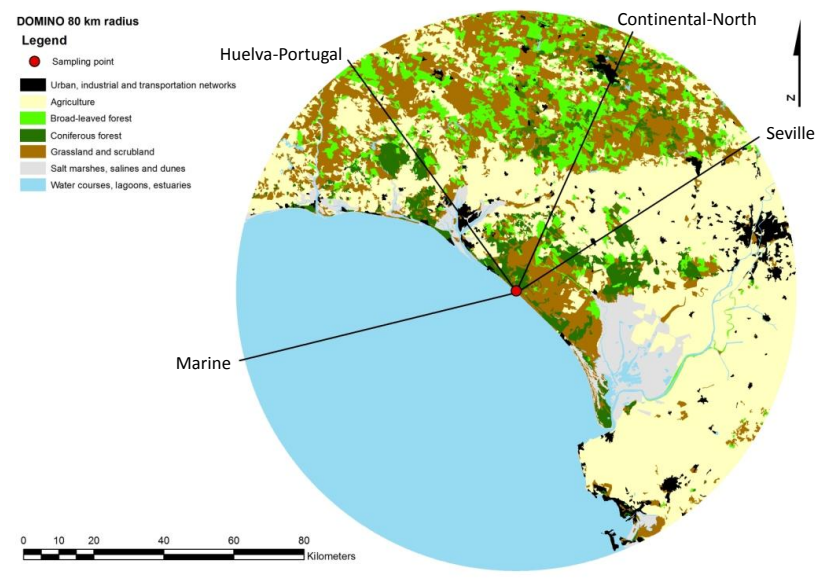

Fig. 2. Distribution of land use within $80 \mathrm{~km}$ of the measurement site. Black lines indicate the last part of the back trajectories cluster means at $100 \mathrm{~m}$.

study is divided into three sectors in their work which are useful for the interpretation of the aerosol chemical composition shown in Diesch et al. (2012). In the investigation carried out by Sinha et al. (2012) three sectors were defined, based on wind measurements and back trajectories. The marine and Huelva sectors are similar while the Continental sector defined in Sinha et al. (2012) is divided in our work into continental-north and Seville.

From wind directions between NE and ESE arrive flows coming from the Guadalquivir valley that have crossed the Seville metropolitan area and the Doñana National Park, therefore this sector has been classified as SevilleGuadalquivir valley. Finally, the air masses coming from between ESE and W from the Atlantic Ocean have been identified as belonging to the marine sector.

The Atlantic Ocean covers approximately $40 \%$ of the area around the site. A semi-quantitative analysis of the land use map in Fig. 2 is given in Table 2. The most significant land use is forests and cultivations. Agriculture (arable land, woody crops and other cultivated areas) reach near to $30 \%$ of the land use. The national and natural parks of Doñana surrounding the sampling site are among Europe's most relevant protected areas due to their populations of migratory birds and sandy landscapes. Nevertheless, many natural or semi-natural forested areas are also frequent $(14.0 \%$ including broadleaved and coniferous forest). Those areas identified as coniferous forests were found to be stone pine (Pinus pinea $\mathrm{L}$.) which has been identified previously as strong terpene emitter in summer (Song et al., 2011). These forests are abundant to the north of the site in the immediate vicinity of the sampling site.
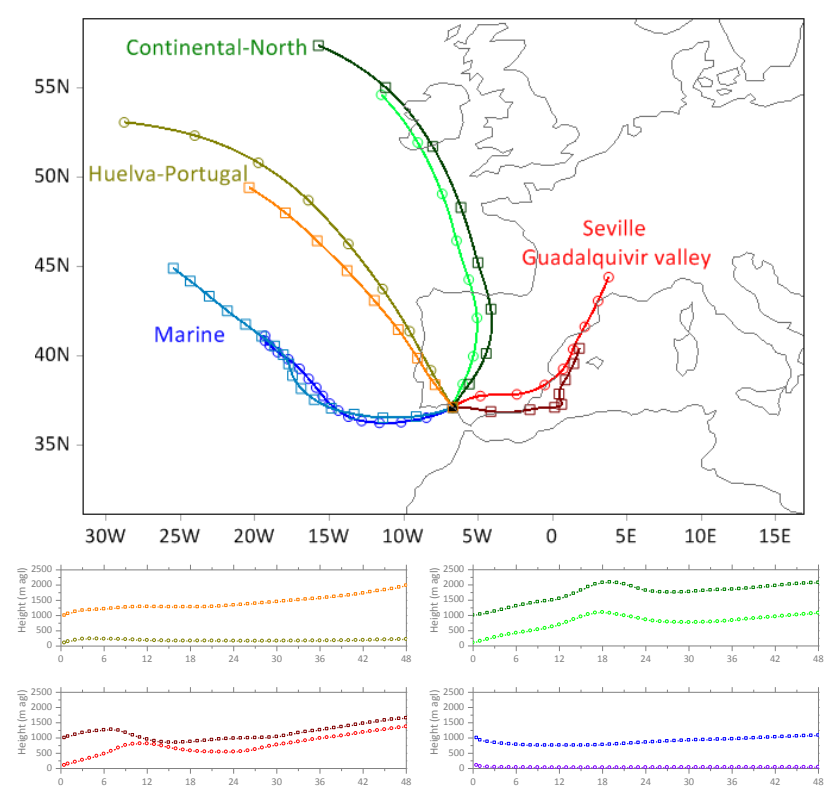

Fig. 3. Back trajectories cluster means (horizontal and vertical variation) of $48 \mathrm{~h}$ computed for 100 and $1000 \mathrm{~m}$ arrival height at El Arenosillo representative of the flows from the Huelva-Portugal, continental-north, Seville-Guadalquivir valley and marine sectors.

\subsubsection{Air mass classification according to source regions and variation with altitude}

One of the goals of the DOMINO campaign was to analyse atmospheric chemistry in air masses of different origins and with distinctively different types of emissions. In order to distinguish between emission loadings of air masses, the hourly back trajectories computed for an altitude of $100 \mathrm{~m}$ at arrival were viewed, selected and were grouped according to their origin from the sectors defined in the last section, rejecting those trajectories that crossed more than one sector before reaching El Arenosillo. The local wind direction agreed with the direction of the trajectories in $>80 \%$ of all cases.

Moreover, hourly back trajectories at five altitudes were computed inside the atmospheric boundary layer (ABL) at $100,250,500,750$ and $1000 \mathrm{~m}$ arrival height in order to study the variation, origin and pathways of the air masses that reached El Arenosillo during DOMINO.

The HYSPLIT model has a tool which allows the grouping of back trajectories into clusters using two parameters, the TSV (minimum increase in total spatial variance between clusters) and the SPVAR (minimum increase of spatial variance between cluster components). This clustering tool has been applied to the back trajectories set obtained for each altitude and sector of origin. A back trajectory mean or cluster has been obtained in each altitude and sector. The results obtained for the five altitudes calculated are very similar, in Fig. 3 the cluster for 100 and $1000 \mathrm{~m}$ altitude for the four sectors are shown. 
Table 2. Land use, total and by sectors of air mass origin. The analysis was carried out within a radius of $80 \mathrm{~km}$ from the sampling site. Each column shows the area $\left(\mathrm{km}^{2}\right)$ of each land use and the percentage of total surface.

\begin{tabular}{|c|c|c|c|c|c|c|c|c|c|c|}
\hline Land use & $80 \mathrm{~km}$ radius & $\%$ & $\mathrm{~S}-\mathrm{G}$ & $\%$ & $\mathrm{C}-\mathrm{N}$ & $\%$ & $\mathrm{H}-\mathrm{P}$ & $\%$ & M & $\%$ \\
\hline Urban, industrial and transportation networks & 410 & 2 & 137 & 5.4 & 52 & 2.1 & 63 & 2.5 & - & - \\
\hline Agriculture & 5921 & 29.5 & 1504 & 59.9 & 677 & 26.9 & 918 & 36.5 & - & - \\
\hline Broad-leaved forest & 1215 & 6 & 181 & 7.2 & 553 & 22 & 292 & 11.6 & - & - \\
\hline Coniferous forest & 843 & 4.2 & 191 & 7.6 & 253 & 10.1 & 216 & 8.6 & - & - \\
\hline Grassland and scrubland & 2829 & 14.1 & 490 & 19.5 & 970 & 38.6 & 838 & 33.3 & - & - \\
\hline Salt marshes, salines and salines & 669 & 3.3 & 0 & 0 & 0 & 0 & 94 & 3.7 & - & - \\
\hline Water courses, lagoons, estuaries & 226 & 1.1 & 11 & 0.4 & 10 & 0.4 & 54 & 2.1 & - & - \\
\hline Ocean & 7993 & 39.8 & - & - & - & - & 39 & 1.6 & 2513 & 100 \\
\hline Total & 20106 & 100 & 2513 & 100 & 2513 & 100 & 2513 & 100 & 2513 & 100 \\
\hline
\end{tabular}

The low variability with the height of the air masses during the DOMINO campaign at 5 different arrival altitudes up to $1000 \mathrm{~m}$ shows that the boundary layer is generally well mixed. Also van Stratum et al. (2012) obtained a similar atmospheric transport at 100 and $2000 \mathrm{~m}$ using trajectories for a specific day (23 November) and meteorological fields of lower spatial resolution. In the following sections the back trajectories obtained for the lowest altitude of $100 \mathrm{~m}$ will be used to discuss the measurement data taken close to the ground.

Air masses with recent anthropogenic emissions, including a strong industrial component coming from Huelva, after crossing the south of Portugal were found in a total of $65 \mathrm{~h}$ (Table 3). Air masses with continental air, from the western and central parts of the Iberian Peninsula affected both by biogenic emissions and by moderate anthropogenic emissions from roads and smaller settlements, possibly also by long-range transport of aged air masses from larger cities like Madrid were identified in a total of $42 \mathrm{~h}$.

Air masses with anthropogenic urban pollution from the Guadalquivir valley, affected by the emissions of the Seville metropolitan area within the last $12 \mathrm{~h}$ of transportation were detected in $41 \mathrm{~h}$. Finally, Atlantic air masses without continental influence during the last $48 \mathrm{~h}$ before reaching $\mathrm{El}$ Arenosillo were observed in $35 \mathrm{~h}$.

\subsection{Overview of the meteorological conditions}

The characterization of weather conditions during the DOMINO campaign is based on local measurements of surface temperature, potential temperature difference between 50 and $10 \mathrm{~m}$, relative and specific humidity, wind direction and speed, ultraviolet radiation, pressure, rainfall and the height of the atmospheric boundary layer (ABL) (Fig. 4). Profiles of potential temperature, specific humidity and wind have been plotted to obtain the structure of the ABL (Seibert et al., 2000), both in stable and unstable (i.e. mixing layer) conditions. The meteorology was further studied on a synoptic level analysing the surface pressure maps and the back trajectories (shown in the last section). Although both synop-
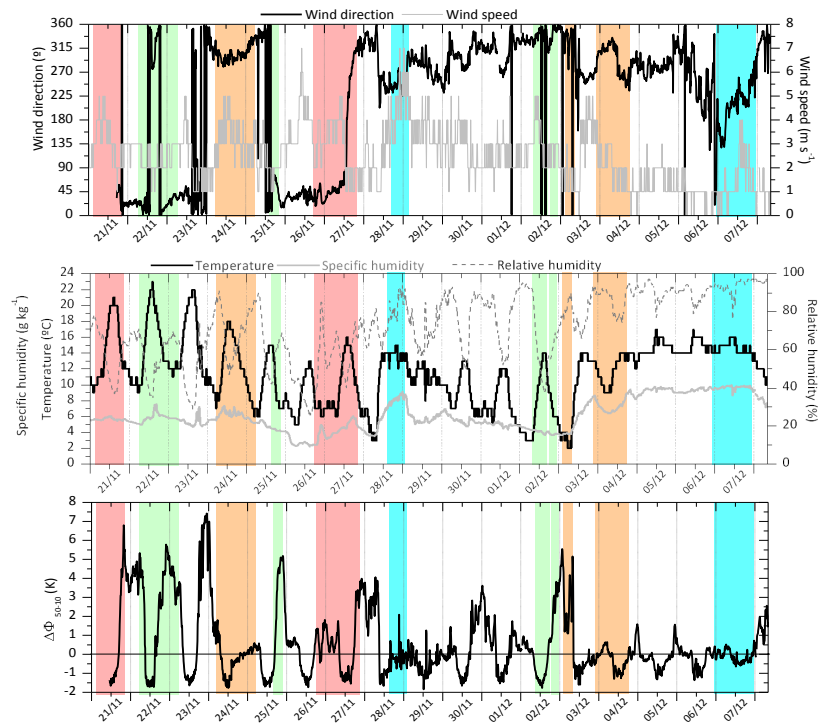

Fig. 4a. Temporal evolution of the wind direction and speed, temperature, relative humidity, specific humidity and potential temperature difference (between 50 and $10 \mathrm{~m}$ ) using $10 \mathrm{~min}$ averages from the whole DOMINO campaign. Periods classified into distinct sectors of air mass origin are marked by brown (Huelva-Portugal), green (continental-north), red (Seville-Guadalquivir) and blue (marine) shaded areas.

tic and mesoscale processes can be developed in this coastal area (Adame et al., 2010a), throughout the whole campaign the weather conditions were governed by synoptic scale motions.

During the first three days of the campaign the air came from the Seville-Guadalquivir valley and continental-north sectors; it was caused by a high pressure system located in the Atlantic Ocean which influenced the Iberian Peninsula. The air masses arriving at the site were located, $48 \mathrm{~h}$ before, in the SE or centre of the Iberian Peninsula, and travelled through the Guadalquivir valley. The days were sunny, as can be observed in the smooth ultraviolet radiation daily cycles almost uninterrupted by clouds. Maximum 
Table 3. Periods classified into distinct sectors of air mass origin.

\begin{tabular}{lllr}
\hline Air mass types & From & To & Hours \\
\hline \multirow{3}{*}{ Huelva-Portugal } & $24 / 11 / 08$ at $06: 00$ & $25 / 11 / 08$ at $06: 00$ & 25 \\
& $03 / 12 / 08$ at $02: 00$ & $03 / 12 / 08$ at $04: 00$ & 3 \\
& $03 / 12 / 08$ at $23: 00$ & $04 / 12 / 08$ at $19: 00$ & 21 \\
& $08 / 12 / 08$ at $09: 00$ & $08 / 12 / 08$ at $24: 00$ & 16 \\
\hline \multirow{3}{*}{ Continental-north } & $22 / 11 / 08$ at $06: 00$ & $23 / 11 / 08$ at $06: 00$ & 25 \\
& $25 / 11 / 08$ at $13: 00$ & $25 / 11 / 08$ at $19: 00$ & 7 \\
& $02 / 12 / 08$ at $10: 00$ & $02 / 12 / 08$ at $15: 00$ & 6 \\
& $02 / 12 / 08$ at $19: 00$ & $02 / 12 / 08$ at $22: 00$ & 4 \\
\hline \multirow{2}{*}{ Seville-Guadalquivir valley } & $21 / 11 / 08$ at $01: 00$ & $21 / 11 / 08$ at $17: 00$ & 17 \\
& $26 / 11 / 08$ at $18: 00$ & $27 / 11 / 08$ at $17: 00$ & 24 \\
\hline \multirow{2}{*}{ Marine } & $28 / 11 / 08$ at $18: 00$ & $29 / 11 / 08$ at $01: 00$. & 8 \\
& $06 / 12 / 08$ at $23: 00$ & $07 / 12 / 08$ at $24: 00$ & 27 \\
\hline
\end{tabular}
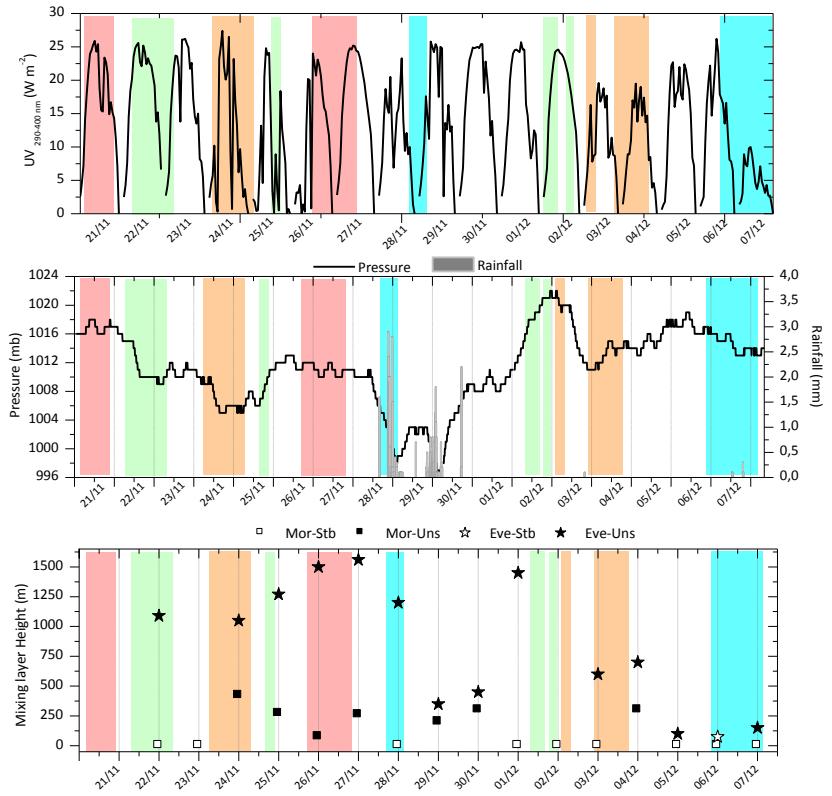

Fig. 4b. Temporal evolution of ultraviolet radiation, pressure and rainfall using $10 \mathrm{~min}$ averages and mixing layer height obtained from soundings (Mor-Stb: morning sounding with stable conditions, Mor-Uns: morning sounding with unstable conditions, EveStb: evening sounding with stable conditions and Eve-Uns: evening sounding with unstable conditions) during the whole DOMINO campaign. Periods classified into distinct sectors of air mass origin are marked by shaded areas as in Fig. 4a.

daily temperatures higher than $20^{\circ} \mathrm{C}$ were reached and welldefined daily temperature cycles were observed; moreover, relative humidity changes between the minimum $(\sim 35 \%)$ and maximum $(\sim 70 \%)$ were also observed. The specific humidity in these continental flows was almost constant, with values around $6-7 \mathrm{~g} \mathrm{~kg}^{-1}$. The mixing layer reached maximum heights (>1000 $\mathrm{m}$ ) around the evening hours, and dur- ing night-time strong inversions built up, with potential temperature differences $>4{ }^{\circ} \mathrm{C}$, the highest of the campaign.

In the late hours of 23 November the synoptic flows were modified due to the displacement from Greenland to the British Isles of a low pressure centre $(989 \mathrm{hPa})$ with a high isobaric gradient. In this new situation the low pressure centre governed the weather in all of western Europe. From late 23 November to midday 25 November local air flows at El Arenosillo were from between the $\mathrm{W}$ and $\mathrm{N}$. The air masses crossed the Iberian Peninsula from $\mathrm{N}$ to $\mathrm{S}$ at first, later coming from the Atlantic Ocean through Portugal and crossing Huelva before reaching El Arenosillo.

Under this new situation, the temperature decreased to daily maxima of $15-18^{\circ} \mathrm{C}$ and minima of $6-8^{\circ} \mathrm{C}$. Associated with maritime flows, the relative humidity was higher than on previous days, while the specific humidity remained similar. The cloudiness during these days increased. During the night of 24 November, no significant nocturnal inversion was built up. The low pressure system continued moving towards the north of Europe and, by late 25 November, it had lost its influence in the SW of Europe.

Another high pressure system now affected the Iberian Peninsula. Flows from between the NE and E occurred, similarly to during the first days of the campaign, from late 25 November to approximately midday on 27 November. The air masses travelled from the centre of the Iberian Peninsula and later from the SW along the Guadalquivir valley. The maximum daily temperatures were lower than on the previous days. A decrease in the relative humidity was also observed (with maximum values ranging between 75 and $85 \%$ ) simultaneously with a decrease of the specific humidity (with mean daily values of $3-4 \mathrm{~g} \mathrm{~kg}^{-1}$, the lowest detected during the campaign).

At high latitudes of the Atlantic Ocean, between Great Britain and Greenland, a new low pressure system was generated, located at the north of the high pressure system. This 
new isobaric configuration started to move towards the European continent.

The Iberian Peninsula was left under a weak isobaric gradient and El Arenosillo received wind from variable directions (mainly from SSE, WNW and $\mathrm{N}$ ), from midday 27 November to approximately 28 November at 08:00 UTC. Other surface meteorological parameters did not change. 28 November marked a clear transition, with the wind veering from NW to SW the origin of air masses changed. Early on 28 November, the air came from the Iberian Peninsula (i.e. the continental-north sector) crossing it from $\mathrm{N}$ to $\mathrm{S}$. Later the air arriving at El Arenosillo had an increasing maritime influence, with wind from the Atlantic Ocean at the end of the day. Both relative and specific humidity increased during the day, reaching maximum values of $94 \%$ and $9 \mathrm{~g} \mathrm{~kg}^{-1}$ respectively. A decrease in pressure (to the lowest values of the campaign) was observed, associated with an enhancement in cloudiness and rainfall in the following night.

The marine influence continued through 29 November. The temperature decreased continuously from 14 to $11^{\circ} \mathrm{C}$ throughout the day without any diurnal maximum. Relative humidity increased up to $90 \%$, while the specific humidity remained similar to the previous day.

On 30 November the low pressure system started to move away from the Iberian Peninsula through the southwest of France, leading to an increase in pressure. This situation remained for the next four days until late 3 December. Local wind was variable, blowing from southwesterly to northwesterly directions. In agreement with the change in the wind direction, maritime air masses were later replaced by air from Portugal and finally from the north of the Iberian Peninsula. Temperature and relative humidity showed well-defined daily cycles, with maxima of $12-14^{\circ} \mathrm{C}$ and of up to $90 \%$ respectively. The specific humidity decreased and cloudiness was low. The evening mixing layer height on 29 and 30 November was significantly lower than on the previous days.

The displacement of the low pressure system towards the European continent favoured the influence of a new high pressure centre, leading to local winds from the NW, HuelvaPortugal sector. On 4 December the synoptic meteorology over the Iberian Peninsula was characterized by a weak isobaric gradient with low wind speeds. Starting on 5 December, the Atlantic anticyclone moved to lower latitudes and the northern part of the Iberian Peninsula was affected by a strong low pressure system $(972 \mathrm{hPa})$ located in the north of the British isles. Due to these conditions, during the last four days of the DOMINO campaign the wind direction was variable; it blew from the NNW and veered to the W-SW, bringing maritime air masses. On 3 December air masses travelled through the south of Portugal and reached El Arenosillo from the NW. With the change in the wind direction to the west, the air showed a strong maritime character, which remained for the last days of the campaign. Weak temperature, relative and specific humidity daily cycles were observed. The temperature varied between 13 and $17{ }^{\circ} \mathrm{C}$, and the relative humidity between 75 and $95 \%$, while the specific humidity reached the highest values of the campaign, oscillating between 8 and $10 \mathrm{~g} \mathrm{~kg}^{-1}$. There was an increase in cloudiness, and in the last hours of 7 December rainfall occurred. Throughout these days, the potential temperature difference between 50 and $10 \mathrm{~m}$ altitude was mostly negative, i.e. without significant nocturnal inversions. In the evening hours the mixing layer hardly reached $750 \mathrm{~m}$ and even atmospheric stable stratification was sometimes observed, as would be expected for a marine boundary layer.

Summarizing, air masses from the Huelva-Portugal, continental-north, Seville-Guadalquivir valley and marine sectors were observed with an occurrence frequency of $42 \%$, $30 \%, 7 \%$ and $21 \%$, respectively. Nevertheless, according to the historical data series the dominant wind direction at this time the year is from the Seville-Guadalquivir and continental-north sectors with an incidence $>40 \%$ each. These air masses are advected from the centre of the Iberian Peninsula or the European continent. Therefore, the wind regime in November and December 2008 was anomalous with respect to the previous $14 \mathrm{yr}$.

Using only air masses with trajectories completely within one of the four sectors defined in Sect. 3.1.3, average diel profiles for temperature, potential temperature difference, specific and relative humidity and wind speed have been calculated for each sector (Fig. 5); in addition, potential temperature and specific humidity vertical profiles are also shown in the same figure.

The meteorological features of the four sectors are quite different. Night-time temperatures differ by up to $6^{\circ} \mathrm{C}$, while daytime average temperatures agree within $2.5^{\circ} \mathrm{C}$. Air from the marine sector showed little diel temperature variation, since the temperature of the air over the ocean is less affected by diurnal heating and nocturnal cooling. By contrast, air with continental influence, i.e. continental-north and Seville-Guadalquivir, shows a clear diel cycle.

Similarly, the potential temperature in marine air was almost equal at 10 and $50 \mathrm{~m}$ altitude during both day and night, whereas air from all other three sectors showed temperature decreasing with altitude by close to $1{ }^{\circ} \mathrm{C}$ in the lowest $50 \mathrm{~m}$ during daytime. The largest vertical potential temperature differences are found in nocturnal stable conditions, with values of up to $5^{\circ} \mathrm{C}$ for the continental-north sector.

The humidity (specific and relative) was relatively low under continental influence (continental-north and SevilleGuadalquivir) and high under marine-sector conditions. Intermediate values were observed in air from the HuelvaPortugal sector. The highest wind speeds were associated with trajectories from the Seville-Guadalquivir sector, probably due to the channelling effect of the Guadalquivir valley. For the continental-north and Huelva-Portugal sectors, wind speeds were similar and the lowest wind speeds occurred under marine conditions, with winds usually being less dispersive. 

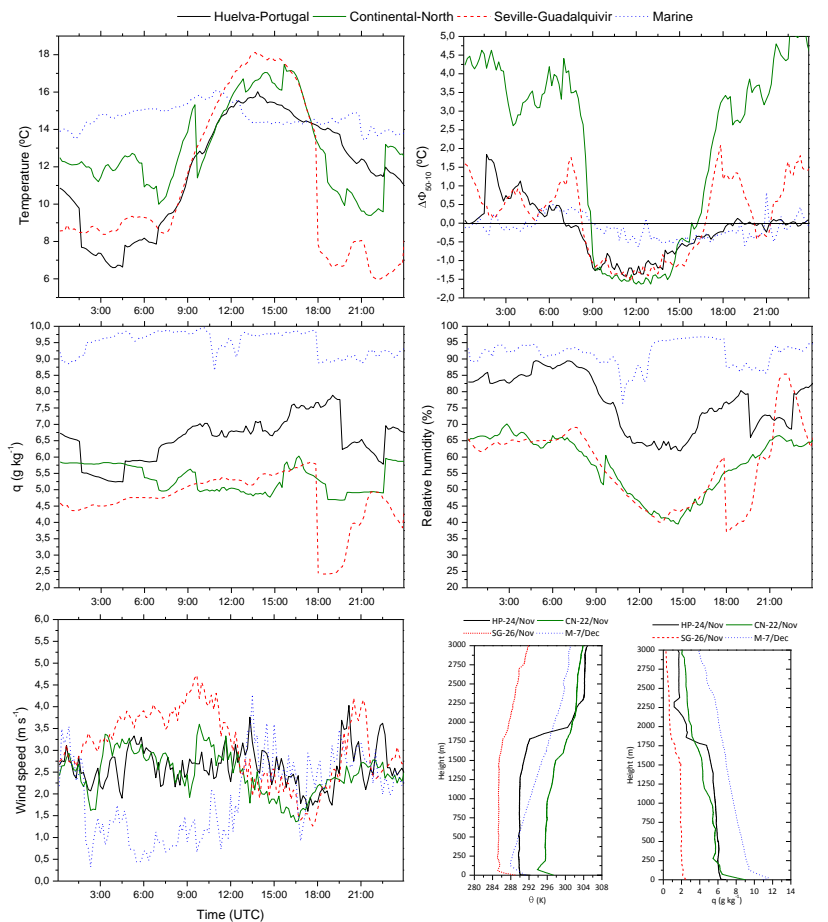

Fig. 5. Average diel profiles of temperature, potential temperature difference, specific and relative humidity and wind speed from the four sectors of origin. Vertical profiles of potential temperature and specific humidity obtained in the afternoon soundings under Huelva-Portugal (H-P on 24 November), continental-north (C-N on 22 November), Seville-Guadalquivir (S-G on 26 November) and marine (M on 7 December) flows.

The atmospheric boundary layer height of air from the continental-north and Seville-Guadalquivir sectors is similar, and the effect of continental conditions while in air from the marine sector is typical of a marine boundary layer. In air masses coming from Huelva-Portugal, both marine and continental influences can be expected.

\subsection{Levels and variation according to the air flow types for $\mathrm{O}_{3}, \mathrm{NO}_{2}, \mathrm{SO}_{2}, \mathrm{OH}$ reactivity, isoprene, benzene, particles and aerosol chemical composition}

An overview of the mixing ratios of chemical trace gases such as ozone, $\mathrm{NO}, \mathrm{NO}_{2}, \mathrm{SO}_{2}$, isoprene and benzene as well as the total $\mathrm{OH}$ reactivity, the number of particles and the aerosol chemical composition measured during DOMINO is given in this section. The whole data series of these species is shown in Fig. 6. The average daily evolution for air of different origins is shown in Fig. 7; averages and standard deviations are given in Table 4 . The daily average for the aerosol chemical composition is displayed in Table 5 .

Surface ozone at El Arenosillo has been monitored since the year 2000 and was used in several studies on ozone under different weather conditions (Adame et al., 2010a, b). During the DOMINO campaign the 10 min ozone data varied be-
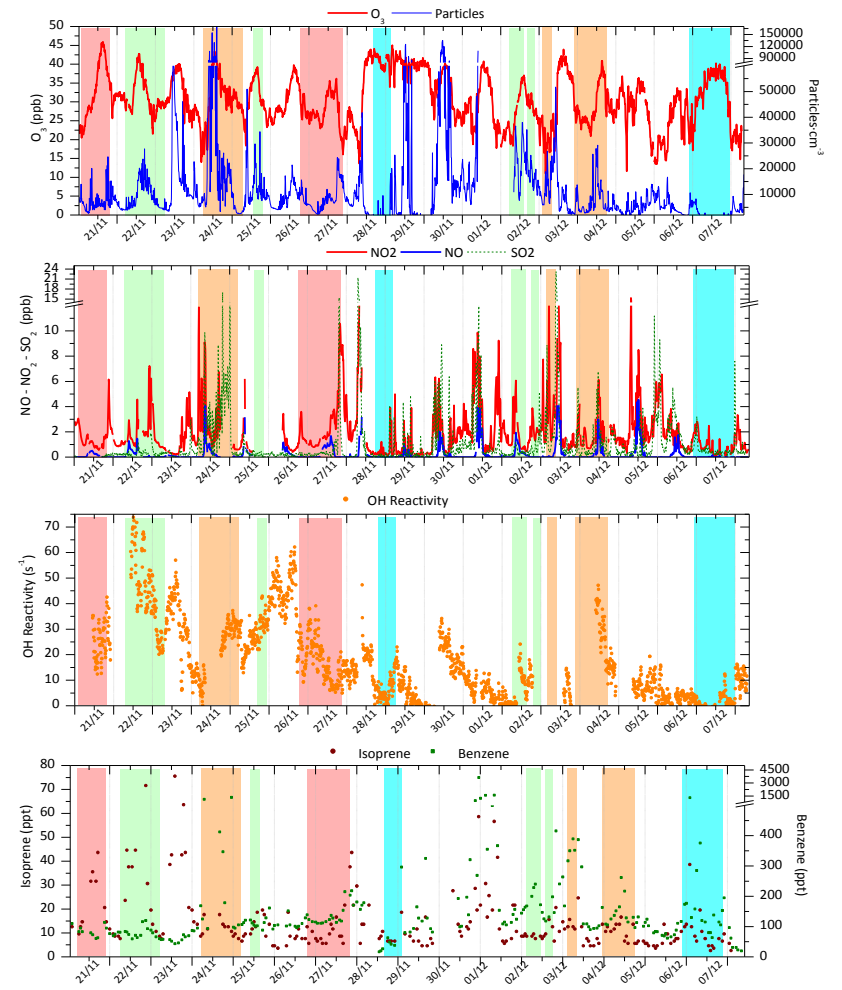

Fig. 6. Mixing ratios of ozone, $\mathrm{NO}, \mathrm{NO}_{2}, \mathrm{SO}_{2}$, particle concentrations, total $\mathrm{OH}$ reactivity (10 min data), isoprene and benzene mixing ratios (hourly data) throughout the DOMINO campaign. Periods classified into distinct sectors of air mass origin are marked by brown (Huelva-Portugal), green (continental-north), red (SevilleGuadalquivir) and blue (marine) shaded areas.

tween 46 and $11 \mathrm{ppb}$. The long-term averages for November and December obtained from the historical data series are $30 \pm 2 \mathrm{ppb}$ and $26 \pm 2 \mathrm{ppb}$ respectively; these are the lowest of the year. Compared with other remote sites in Europe, these values are similar to those found in Hohenpeißenberg during this time of year ( $29 \pm 2 \mathrm{ppb}$, Gilge et al., 2010) and lower than in Mace Head $(41 \pm 2 \mathrm{ppb}$, Parrish et al., 2013). The average for DOMINO was a little higher, with $31 \pm 7 \mathrm{ppb}$. Throughout the campaign a clear daily cycle was observed for ozone with maximum values of up to $35 \mathrm{ppb}$ in the afternoon, approximately $1-1.5 \mathrm{~h}$ later than the maximum solar radiation. An exception to this was the period from 28 to 30 November, when ozone remained almost constant for over $36 \mathrm{~h}$.

Average diel ozone profiles were quite similar for all air mass origins during daytime, indicating no significant or low photochemical production in more polluted air. Significant differences were found mostly during night-time, indicating different levels of ozone destruction. The highest values were recorded for the relatively clean marine air $(34 \pm 6 \mathrm{ppb})$, and the lowest for continental air coming from continental-north and Seville-Guadalquivir sectors ( $30 \pm 6 \mathrm{ppb})$. 
Table 4. Data number $(N)$, average and standard deviation $(\mathrm{Av} \pm \sigma)$ in $\mathrm{ppb}\left(\mathrm{O}_{3}, \mathrm{NO}, \mathrm{NO}_{2}, \mathrm{SO}_{2}\right)$, ppt (isoprene and benzene), particles cm ${ }^{-1}$ (particles) and $\mathrm{s}^{-1}(\mathrm{OH}$ reactivity) for the whole campaign and for data classified into distinct sectors of air mass origin: Huelva-Portugal (H-P), continental-north (C-N), Seville-Guadalquivir (S-G) and marine (M).

\begin{tabular}{|c|c|c|c|c|c|c|c|c|c|c|}
\hline & \multicolumn{2}{|c|}{ Whole campaign } & \multicolumn{2}{|r|}{$\mathrm{H}-\mathrm{P}$} & \multicolumn{2}{|r|}{$\mathrm{C}-\mathrm{N}$} & \multicolumn{2}{|r|}{$S-G$} & \multicolumn{2}{|r|}{ M } \\
\hline & $N$ & $\mathrm{Av} \pm \sigma$ & $N$ & $\mathrm{Av} \pm \sigma$ & $N$ & $\mathrm{Av} \pm \sigma$ & $N$ & $\mathrm{Av} \pm \sigma$ & $N$ & $\mathrm{Av} \pm \sigma$ \\
\hline $\mathrm{O}_{3}$ & 2469 & $31 \pm 7$ & 294 & $30 \pm 6$ & 246 & $32 \pm 4$ & 252 & $30 \pm 6$ & 207 & $34 \pm 6$ \\
\hline Particles & 2362 & $11297 \pm 15808$ & 294 & $16614 \pm 23956$ & 252 & $12778 \pm 7432$ & 252 & $7104 \pm 3539$ & 208 & $1652 \pm 2184$ \\
\hline NO & 2181 & $0.2 \pm 0.5$ & 226 & $0.3 \pm 0.7$ & 196 & $0.2 \pm 0.3$ & 232 & $0.2 \pm 0.4$ & 185 & $0.0 \pm 0.0$ \\
\hline $\mathrm{NO}_{2}$ & 2181 & $1.9 \pm 1.9$ & 226 & $2.1 \pm 1.7$ & 196 & $1.7 \pm 1.3$ & 232 & $1.6 \pm 0.8$ & 185 & $0.7 \pm 0.7$ \\
\hline $\mathrm{SO}_{2}$ & 2481 & $1.0 \pm 2.1$ & 294 & $2.1 \pm 2.5$ & 246 & $0.3 \pm 0.3$ & 249 & $0.1 \pm 0.3$ & 208 & $0.5 \pm 0.4$ \\
\hline $\mathrm{OH}$ react & 1880 & $18 \pm 15$ & 147 & $25 \pm 10$ & 193 & $35 \pm 17$ & 176 & $20 \pm 8$ & 177 & $1.5 \pm 2.8$ \\
\hline Benzene & 1357 & $179 \pm 285$ & 175 & $241 \pm 262$ & 168 & $108 \pm 71$ & 151 & $108 \pm 31$ & 63 & $59 \pm 58$ \\
\hline Isoprene & 1327 & $15 \pm 17$ & 175 & $10 \pm 3$ & 168 & $28 \pm 31$ & 151 & $14 \pm 10$ & 39 & $6 \pm 3$ \\
\hline
\end{tabular}

Table 5. Daily levels of $\mathrm{PM}_{10}, \mathrm{PM}_{2.5}, \mathrm{PM}_{10-2.5}$ and major $\left(\mu \mathrm{g} \mathrm{m}^{-3}\right.$ ) and trace components (in $\mathrm{ng} \mathrm{m}^{-3}$ ) for $\mathrm{PM}_{10}$ in the Huelva-Portugal (H-P), continental-north $(\mathrm{C}-\mathrm{N})$, SevilleGuadalquivir (S-G) and marine $(\mathrm{M})$ sectors.

\begin{tabular}{|c|c|c|c|c|}
\hline & \multicolumn{4}{|c|}{ Major components (in $\mu \mathrm{g} \mathrm{m}^{3}$ ) } \\
\hline & $\mathrm{H}-\mathrm{P}$ & $\mathrm{C}-\mathrm{N}$ & $\mathrm{S}-\mathrm{G}$ & M \\
\hline $\mathrm{PM}_{10}$ & 21.87 & 10.85 & 4.89 & 13.06 \\
\hline $\mathrm{PM}_{2.5}$ & 11.38 & 8.21 & 3.48 & 10.49 \\
\hline $\mathrm{PM}_{10-2.5}$ & 10.49 & 2.64 & 1.41 & 2.57 \\
\hline $\mathrm{Ca}$ & 0.05 & 0.23 & 0.15 & 0.052 \\
\hline $\mathrm{Fe}$ & 0.39 & 0.42 & 0.43 & 0.100 \\
\hline $\mathrm{K}$ & 1.38 & 0.00 & 0.00 & 3.48 \\
\hline $\mathrm{Mg}$ & 0.14 & 0.02 & 0.02 & 0.10 \\
\hline \multirow[t]{3}{*}{$\mathrm{Na}$} & 0.00 & 0.00 & 0.00 & 8.50 \\
\hline & \multicolumn{4}{|c|}{ Trace components (in $\mathrm{ng} \mathrm{m}^{3}$ ) } \\
\hline & $\mathrm{H}-\mathrm{P}$ & $\mathrm{C}-\mathrm{N}$ & $\mathrm{S}-\mathrm{G}$ & M \\
\hline As & 7.63 & 0.00 & 0.00 & 5.65 \\
\hline $\mathrm{Cd}$ & 0.28 & 0.00 & 0.00 & 0.00 \\
\hline $\mathrm{Co}$ & 0.27 & 0.00 & 0.00 & 0.00 \\
\hline $\mathrm{Cu}$ & 18.47 & 10.37 & 3.69 & 14.20 \\
\hline $\mathrm{Mn}$ & 5.55 & 7.64 & 6.05 & 2.64 \\
\hline $\mathrm{Ni}$ & 4.96 & 4.53 & 3.14 & 3.01 \\
\hline $\mathrm{P}$ & 21.67 & 18.05 & 16.65 & 11.81 \\
\hline $\mathrm{Pb}$ & 9.71 & 5.14 & 3.47 & 7.33 \\
\hline S & 609.62 & 291.72 & 272.73 & 418.81 \\
\hline $\mathrm{Sc}$ & 0.00 & 0.00 & 0.00 & 0.00 \\
\hline $\mathrm{Se}$ & 0.72 & 0.00 & 0.00 & 0.00 \\
\hline $\mathrm{Si}$ & 83.96 & 114.62 & 122.97 & 0.00 \\
\hline $\mathrm{Sn}$ & 1.41 & 1.97 & 1.60 & 1.95 \\
\hline $\mathrm{Sr}$ & 0.90 & 0.00 & 0.05 & 1.30 \\
\hline $\mathrm{Ti}$ & 36.42 & 21.64 & 16.69 & 37.77 \\
\hline $\mathrm{V}$ & 3.00 & 0.92 & 1.24 & 2.09 \\
\hline $\mathrm{Zn}$ & 17.67 & 0.00 & 0.00 & 154.70 \\
\hline
\end{tabular}

The total particle concentration greater than $2.5 \mathrm{~nm}$ diameter measured with $10 \mathrm{~min}$ time resolution was $(11.3 \pm 15.8) \times 10^{3}$ particles $\mathrm{cm}^{-3}$ during the DOMINO campaign. The total particle concentration with diameters within $14-675 \mathrm{~nm}$ is also routinely measured at El Arenosillo, and shows an annual mean level of $(8.6 \pm 6.7) \times 10^{3} \mathrm{~cm}^{-3}$ (Sorribas et al., 2011). Differences between the mean total particle concentration reported in Sorribas et al. (2011) and during DOMINO could be due to the different particle size ranges used for the two studies. The highest particle concentrations are observed close to noon, and the lowest were observed during night-time. At El Arenosillo, the diurnal maximum may be attributed to new particle formation events from biogenic or anthropogenic precursors. Diel profiles for the different air mass origins show that the total particle concentrations during night-time are similarly low for air from all sectors. However, during daytime the total particle concentration is highly variable. Air masses coming from the marine and the SevilleGuadalquivir sectors did not show maxima at noon, indicating that no nucleation events occurred during transport from these sectors. Particle levels were very different with an average of $(1652 \pm 2184)$ particles $\mathrm{cm}^{-3}$ for the marine and (7104 \pm 6905$)$ particles $\mathrm{cm}^{-3}$ for the Seville-Guadalquivir sectors. For the particle concentration, the continental-north sector shows the typical diel profile of a nucleation event, as corroborated by measurements of sub-micron size distributions evidencing intensive particle formation as well as continuous growth (Diesch et al., 2012). During sunrise, new particles were formed by photochemical processes and the total particle concentration increased around 10:00 UTC. From 10:00 UTC to 11:00 UTC, the mixing processes start increasing the height of the boundary layer and decreasing its particle concentration. When the nucleation velocity becomes higher than the dilution velocity, the particle concentration increases again at around 12:00 UTC. In the evening, the particle coagulation and condensation processes produce a slow decrease of the particle concentration within the size range measured by the UCPC. The highest noon levels were measured in air masses coming from the Huelva-Portugal sector, and are likely due to secondary particle formation 

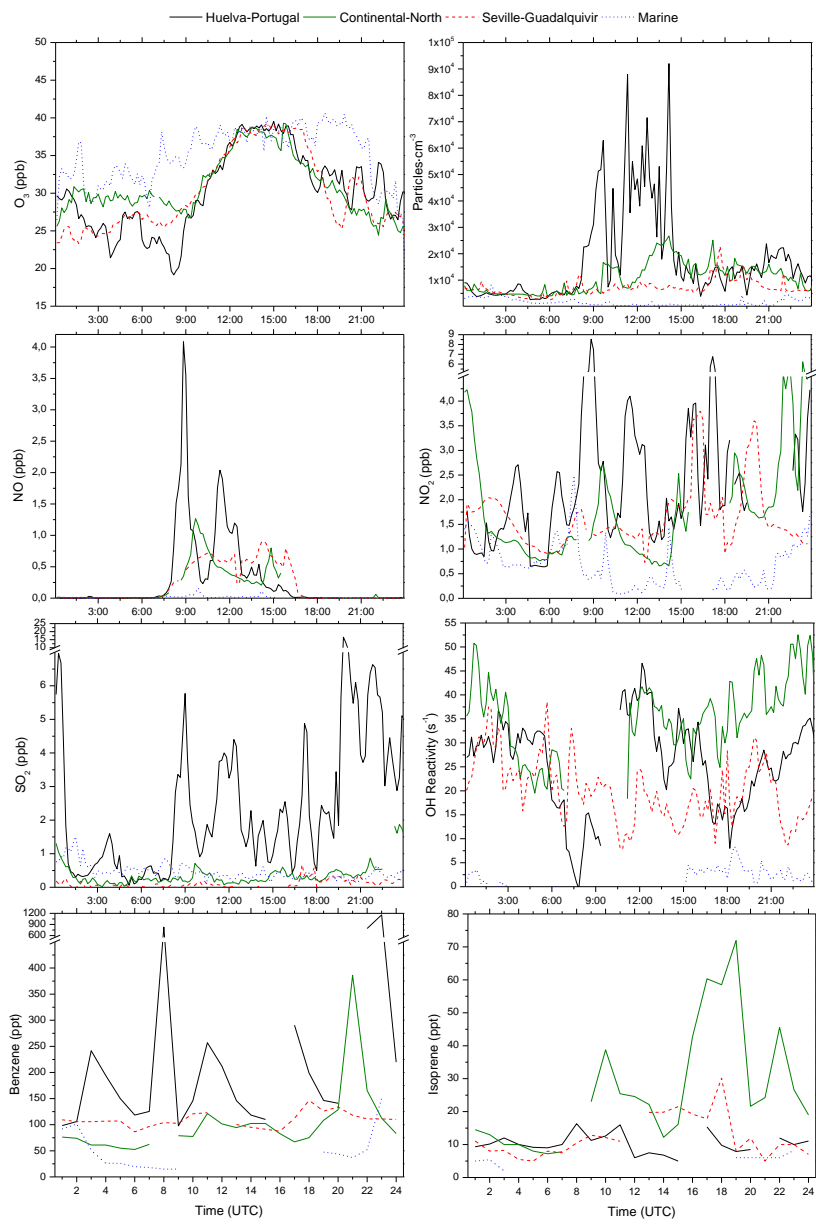

Fig. 7. Mean diel variation for ozone, particles with $D>2.5 \mathrm{~nm}$, $\mathrm{NO}, \mathrm{NO}_{2}, \mathrm{SO}_{2}$, total $\mathrm{OH}$ reactivity, benzene and isoprene for air with different origin.

from emissions of the industrial areas situated around Huelva city.

Since El Arenosillo is a rural environment without $\mathrm{NO}_{\mathrm{x}}$ emission sources nearby, average mixing ratios measured of $\mathrm{NO}$ and $\mathrm{NO}_{2}$ were relatively low $(0.2 \pm 0.5 \mathrm{ppb}$ and $1.9 \pm 1.9 \mathrm{ppb}$ respectively) compared to other remote sites in Europe like Hohenpeißenberg during this time of year (3.6 \pm 0.3 ppb $\mathrm{NO}_{2}$, Gilge et al., 2010). The NO levels are close to zero during the night-time, due to titration with $\mathrm{O}_{3}$ forming $\mathrm{NO}_{2}$.

During night-time, the highest $\mathrm{NO}_{2}$ mixing ratios were observed in air from the continental-north, indicating important sources to the north of El Arenosillo, likely from the industrial emissions. Hourly time-of-day average NO mixing ratios exceeded $4 \mathrm{ppb}$ and were observed in air from the Huelva-Portugal sector. A rapid increase is observed in the early morning, when the daily maximum is reached, coinciding with the maximum mixing ratios of 9 ppb $\mathrm{NO}_{2}$, likely due to accumulation in the stable nocturnal residual layer, mixing down to the ground with the breaking of the inversion layer and partly photolysing to $\mathrm{NO}$ in the morning sunlight. $\mathrm{NO}_{2}$ mixing ratios were about $50 \%$ higher in air from HuelvaPortugal than in air from the other inshore sectors. During daytime, air passing Seville-Guadalquivir has similar $\mathrm{NO}_{2}$ loadings as air from more northerly sectors. The lowest $\mathrm{NO}_{2}$ was recorded in marine-sector air; it was a few 100 ppt during daytime and around $1 \mathrm{ppb}$ during night-time.

The variability of $\mathrm{SO}_{2}$ during the campaign is associated with the arrival of air masses loaded with $\mathrm{SO}_{2}$, and it showed no diel cycles. The daily cycle of $\mathrm{SO}_{2}$ is not detectable because it is below detection limit in most air masses; by contrast, in air from the Huelva-Portugal sector, the dominant sources are point sources and mixing ratio of $\mathrm{SO}_{2}$ on-site therefore depends strongly on the air trajectory. Mixing ratios varied between the limit of detection ( $1 \mathrm{ppb})$ and a maximum of $23 \mathrm{ppb}-1.0 \pm 2.1 \mathrm{ppb}$ in average. $\mathrm{SO}_{2}$ shows some very elevated values in Huelva-Portugal air $(2.1 \pm 2.5 \mathrm{ppb}$ in average) compared to air from other sectors, except during nighttime between 01:00 and 08:00 UTC. The origin of these mixing ratios could be attributed to industrial emissions. The lowest values were observed in Seville-Guadalquivir air $(0.1 \pm 0.3 \mathrm{ppb}$ in average), reflecting lowest influence of local industrial pollution in this sector. The continental-north sector has some mixing in of Huelva industrial air during nighttime, evidenced by elevated $\mathrm{SO}_{2}$ around midnight and due to the strong vertical stability observed in nocturnal air from this sector. Marine air also has more $\mathrm{SO}_{2}$ than Seville air $(0.5 \pm 0.4$ vs. $0.1 \pm 0.3 \mathrm{ppb})$, more likely due to ship emissions than to influence by local industrial pollution, since night-time values after 01:00 UTC are often higher in marine air $(1.2 \pm 0.5 \mathrm{ppb})$ than in Huelva air $(0.7 \pm 0.5 \mathrm{ppb})$.

During the campaign $\mathrm{OH}$ reactivity was measured by Sinha et al. (2012); it ranged from below limit of detection $\left(3.5 \mathrm{~s}^{-1}\right)$ to $76 \mathrm{~s}^{-1}$, with a mean value during the campaign of $18 \pm 15 \mathrm{~s}^{-1}$. The highest values were observed in air from northerly directions during night-time. Although Huelva-Portugal air reaches similarly high values in the afternoon as does continental-north air, when vertical mixing is highest, values are significantly lower from 15:00 to $02: 00\left(25 \pm 16 \mathrm{~s}^{-1}\right.$ for Huelva-Portugal and $39 \pm 8 \mathrm{~s}^{-1}$ for continental-north), indicating that Huelva sources play a smaller role than long-range transported species for $\mathrm{OH}$ reactivity. Air masses from the Seville-Guadalquivir sector also show generally lower $\mathrm{OH}$ reactivities $\left(20 \pm 8 \mathrm{~s}^{-1}\right)$ than continental air from northerly directions $\left(35 \pm 17 \mathrm{~s}^{-1}\right)$. Marine air shows by far the lowest $\mathrm{OH}$ reactivities $\left(1.5 \pm 2.8 \mathrm{~s}^{-1}\right)$. This is consistent with results obtained by Sinha et al. (2012), which also show highest values for Continental air and lowest values for marine air. They used a less restrictive classification with only three sectors; these include data points which we reject due to possible mixing of air from different sectors. Thus their diel profiles differ from the ones shown here. Even so their conclusions are consistent with ours, supporting the validity of their approach. 
Although an overview of the VOC measurements during the campaign was published by Song et al. (2011), in this work benzene and isoprene have been selected as representative of anthropogenic (urban-industrial emissions) and biogenic VOCs respectively. Benzene was measured with an average mixing ratio of $179 \pm 285 \mathrm{ppt}$ during the campaign and maximum and minimum mixing ratios of 3461 and $12 \mathrm{ppt}$. Isoprene displayed a mean mixing ratio of $15 \pm 17 \mathrm{ppt}$, and maximum and minimum values of 137 and 2 ppt respectively. Both benzene and isoprene were strongly affected by air mass origin. As VOC mixing ratios are generally low in marine air, little isoprene and benzene were found in air from this sector, Benzene in air coming from HuelvaPortugal sector with $241 \pm 262 \mathrm{ppb}$ in average is about double and much more variable than in air from the continentalnorth (108 $\pm 71 \mathrm{ppb}$ in average) and Seville-Guadalquivir (108 $\pm 31 \mathrm{ppb}$ ), being the Huelva-Portugal sector being the main source of this emission. Isoprene (biogenic) has a maximum in the afternoon, due to the diurnal cycle of biogenic emissions. The highest isoprene mixing ratios were observed in air from the continental-north (the main source of biogenic emissions, with $28 \pm 31 \mathrm{ppb}$ in average), while the afternoon maximum in Seville-Guadalquivir air was much smaller $(14 \pm 10 \mathrm{ppb})$, and no significant diurnal variation was found in the Huelva-Portugal sector $(10 \pm 3 \mathrm{ppb})$. This indicates a larger role of biogenic VOCs for $\mathrm{OH}$ reactivity than from recent anthropogenic VOC emissions.

Aerosol chemical composition was analysed thanks to samples collected on filters each $24 \mathrm{~h}$. Laboratory analysis was used to obtain the daily levels of $\mathrm{PM}_{10}, \mathrm{PM}_{2.5}, \mathrm{PM}_{10-2.5}$ and the major and trace element components for $\mathrm{PM}_{10}$ measured during DOMINO. Table 5 gives the mean values, standard deviations and maximum and minimum daily values for each parameter. A particle-size prevalence was not observed, given that mean $\mathrm{PM}_{2.5}$ was $55 \%$ of the mean $\mathrm{PM}_{10}$ fraction $\left(16 \mu \mathrm{g} \mathrm{m}^{-3}\right.$ for $\mathrm{PM}_{10}$ and $9 \mu \mathrm{g} \mathrm{m}^{-3}$ for $\left.\mathrm{PM}_{2.5}\right)$. These results agree with the ranges of mean annual values across Spanish background sites for $\mathrm{PM}_{10}$ and $\mathrm{PM}_{2.5}$, though it is lower than mean annual values for southern Spain (Querol et al., 2002, 2008; Sánchez de la Campa et al., 2009). This is related to the season when the DOMINO campaign took place, without impact of desert dust aerosol which usually increases $\mathrm{PM}_{10}$ and $\mathrm{PM}_{2.5}$ levels across the south of Spain.

Analyses of concentrations of major components highlight $\mathrm{Na}$ and $\mathrm{K}$ since they exhibit the highest levels in comparison to previous analysis in the south of Spain (De la Rosa et al., 2010) $-2.66 \mu \mathrm{g} \mathrm{m}^{-3}$ and $1.08 \mu \mathrm{g} \mathrm{m}^{-3}$, respectively. Both components show a moderate correlation with $\mathrm{Zn}$ concentrations ( $r=0.54$ and 0.60 respectively), which could be due to the presence of marine air masses during DOMINO campaign.

The potassium compound could be also related to the industrial activities around Huelva city. $\mathrm{Fe}, \mathrm{Si}$ and $\mathrm{Mn}$ are natural crustal elements associated with continental air masses.
Additionally, high particle concentration levels of As and $\mathrm{Cu}$ were found in comparison to those at other sampling sites in southern Spain. However, even with the unusual contribution from the Huelva-Portugal sector that occurred during the DOMINO campaign, As and $\mathrm{Cu}$ concentrations are lower than and similar to, respectively, the annual mean measured in this area in previous studies (De la Rosa et al., 2010). Arsenic levels presented a high correlation with $\mathrm{Pb}(r=0.93)$, $\mathrm{Cu}(r=0.86), \mathrm{Cd}(r=0.87)$ and a moderate correlation with $\mathrm{P}(r=0.70)$ and $\mathrm{Se}(r=0.65)$.

In order to perform a study for the different sectors of air mass origin defined above, clustering of the data for mass concentration and chemical composition has been carried out. For each filter, the fraction of time with air masses coming from each sector was calculated. If the fraction for a given sector was higher than $60 \%$, the sampled filter was considered as representative of this sector.

Applying this methodology, two filters were considered as representative of the Huelva-Portugal sector, measured on 24 November and 8 December; one filter corresponding to continental-north, measured on 22 November; one filter as belonging to the Seville-Guadalquivir sector, measured on 26 November; and one representative of the marine sector, measured on 7 December. Table 5 shows the daily levels of $\mathrm{PM}_{10}, \mathrm{PM}_{2.5}, \mathrm{PM}_{10-2.5}$ and major and trace elements components for $\mathrm{PM}_{10}$ by sectors.

Mean $\mathrm{PM}_{10}$ concentrations ranged from $5 \mu \mathrm{g} \mathrm{m}^{-3}$ (for the Seville-Guadalquivir sector) to $22 \mu \mathrm{g} \mathrm{m}^{-3}$ (for the HuelvaPortugal sector) and equivalent results have been found for $\mathrm{PM}_{2.5}$. The high $\mathrm{PM}_{10}$ and $\mathrm{PM}_{2.5}$ concentrations in the Huelva sector are most likely due to the particle contributions of the industrial activities around Huelva City.

Natural crustal elements ( $\mathrm{Fe}, \mathrm{Mn}$ and $\mathrm{Si}$ ) from the ground were detected mostly for the continental-north and SevilleGuadalquivir sectors due to the continental influence (Kothai et al., 2011), while the highest values of $\mathrm{Na}$ and $\mathrm{K}$ were detected in air from the marine sector.

The group of trace elements which are considered to be main components of natural marine emissions in the gasphase (e.g. S and As) and sea-salt particles have been found mainly in air from the marine sector (e.g. $\mathrm{Cu}, \mathrm{Ni}, \mathrm{Pb}$ and $\mathrm{Zn}$ ).

\section{Discussion}

Derived from a study of the weather conditions during the campaign, using observational data (from the surface, elevated height and soundings) and modelling tools to calculate the air masses back trajectories as well as a land use map, we are able to distinguish four sectors of air mass origin with distinct sources: Huelva-Portugal, continental-north, SevilleGuadalquivir and marine. Together with an overview of the chemical species for the entire campaign, the analysis of the different air masses according to their sector of origin is of 
special interest, evidencing distinct atmospheric and chemical features.

\subsection{Huelva-Portugal sector}

Air masses from the urban-industrial area of Huelva, which came from the Atlantic Ocean and across the south of Portugal, were the most frequent during the campaign. Nevertheless, this air flow is unusual for this time of year. Air from this sector showed the lowest temperatures both during day and night, intermediate values of humidity (relative and specific), and relatively constant wind speeds throughout the day, with a slight decrease in the afternoon. From midnight to sunrise inversion layers developed with similar intensity as in air from the Seville-Guadalquivir sector but lower than in air from the continental-north. Unstable conditions developed during the approximately eight daylight hours, with a mixing layer height in the afternoon of around $1000 \mathrm{~m}$. These atmospheric features are associated with both maritime and continental influences.

From midnight to sunrise, under more stable atmospheric conditions, horizontal transport from the Huelva industrial area reached the measurement area in less than $3 \mathrm{~h}$. The wind speed of $\sim 2.5 \mathrm{~m} \mathrm{~s}^{-1}$ and the distance of $25 \mathrm{~km}$ favour the arrival of the air pollutants before they are removed by chemical or deposition processes. Under these air flows and during this nocturnal period, the highest mixing ratios of benzene, $\mathrm{SO}_{2}$ and $\mathrm{NO}_{2}$, and the lowest of ozone were measured. The sunrise brings the breaking of the inversion layer and the formation of the mixing layer. Between 08:00 to 10:00 UTC a marked decrease in the values of ozone and $\mathrm{OH}$ reactivity was observed, while $\mathrm{SO}_{2}$, total particles concentrations, $\mathrm{NO}$, $\mathrm{NO}_{2}$ and benzene exhibited daily peaks. The values measured can have a double origin: fresh emissions released $2 \mathrm{~h}$ before by the industry and transported horizontally in the still shallow and undiluted boundary layer, together with aged emissions accumulated in upper residual layers being mixed down as the night-time inversion breaks up in the morning. The large NO increase strongly suggests the first possibility. Under unstable boundary layer conditions (i.e. during daytime) the highest values of the campaign for total particle concentration, $\mathrm{NO}, \mathrm{NO}_{2}, \mathrm{SO}_{2}, \mathrm{OH}$ reactivity and benzene were found. The air pollutants emitted in the industrial area reached El Arenosillo in less than $3 \mathrm{~h}$. Ozone mixing ratios were similar to those in air from other sectors. Isoprene values were more or less constant throughout the day with maximum mixing ratios $<20$ ppt. Between Huelva and El Arenosillo there are many agroforestry and cultivated areas, coniferous and Mediterranean forest being irrelevant in comparison with other sectors. This explains the lower values of isoprene when wind came from this sector.

In the last hours of the day, between 20:00 and midnight, under stable-neutral conditions and a slight increase in the wind speed (i.e. favouring the air pollutant accumulation close to the ground), a rise of ozone, $\mathrm{NO}_{2}, \mathrm{SO}_{2}$ (daily peak),
$\mathrm{OH}$ reactivity and benzene (daily peak) was detected while the total particle concentration remained low.

The chemical composition indicates metallurgical activities for $\mathrm{Cu}$ production (mainly $\mathrm{As}, \mathrm{Cd}, \mathrm{Cu}, \mathrm{Zn}, \mathrm{Ni}$ and $\mathrm{Pb}$ ), a power plant (mainly $\mathrm{As}, \mathrm{Cd}, \mathrm{Ni}$ and $\mathrm{Zn}$ ) and industrial activities based on the production of phosphate products and phosphoric acid (mainly P). Also typical tracers of combustion emissions ( $\mathrm{S}, \mathrm{V}$ and $\mathrm{Se}$ ) were observed (Grahame and Hidy, 2004; Frossard et al., 2011).

Although air masses coming from the sector identified as Huelva-Portugal can have contributions from Portugal or even the marine sector, this is not evident in our results. The elevated levels of species such as $\mathrm{SO}_{2}, \mathrm{NO}_{2}$, benzene, total particle concentration, $\mathrm{As}, \mathrm{Cu}$, etc., recorded during DOMINO under this atmospheric regime are clearly associated with the industrial emissions since the emission inventory includes these same species. High local emissions, at distances too short from the sources to produce significant dispersion or elimination, combined with the atmospheric neutral-stable conditions are the main factors leading to these elevated concentrations. In addition, the highest $\mathrm{PM}_{10}$ and $\mathrm{PM}_{10-2.5}$ concentrations are found in this sector, at $21.9 \mu \mathrm{g} \mathrm{m}^{-3}$ and $10.5 \mu \mathrm{g} \mathrm{m}^{-3}$, respectively.

\subsection{Continental-north sector}

Air reaching El Arenosillo from the continental-north sector is not affected by the urban-industrial area of Huelva. The structure of the lower atmosphere is strongly affected by the thermal contrast between day and night, showing a structure typical of the PBL (planet boundary layer). The daily temperature cycles are very marked with thermal amplitudes of up to $8^{\circ} \mathrm{C}$; the humidity levels are the lowest together with those in the Seville-Guadalquivir air. During the night the highest thermal inversions of the whole campaign where observed, likewise, under unstable vertical conditions during daytime, the mixing layer height in the afternoon was close to $1000 \mathrm{~m}$, similar to the Huelva-Portugal sector.

From midnight to sunrise generally low values of total particle concentration, $\mathrm{NO}_{2}, \mathrm{SO}_{2}$ and benzene were detected, whereas $\mathrm{OH}$ reactivity shows a decreasing trend. The nocturnal ozone under these conditions is constant at high levels, lower only than ozone from the marine sector, due to the strong thermal inversion and the relatively absence of low anthropogenic emissions. After sunrise, between 09:00 to 10:00 UTC, the nocturnal stable boundary layer breaks up and an increase of ozone, NO, benzene, isoprene and even the total particle concentration are observed. In this sector the emission sources have mainly a biogenic origin. According to our land use analysis, the main land use in the north of El Arenosillo is natural and semi-natural vegetation. Wide extents of transitional woodland shrubs and coniferous forest play an important role in the dynamics of biogenic emissions in the vicinity of sampling site, particularly in summer. Possible anthropogenic sources which could affect air 
from this sector are the Huelva-Seville motorway and a cement industry located at a $30 \mathrm{~km}$ distance from the measurement area. Assuming that the particles origin was the anthropogenic emissions and using the wind speeds recorded, the emissions would have occurred $3 \mathrm{~h}$ before (around 06:00 and 08:00 UTC). However, during the night and under the same conditions of horizontal transport, much lower mixing ratios were measured; hence is unlikely that these are the main sources of the morning increase. Like for the air coming from Huelva and under the influence of even stronger nocturnal atmospheric stability, residual layers developed which were mixed into the boundary layer in the early morning, leading to an increase of aged air pollutants and particles at ground level. This is also supported by the isoprene increase, since the first peak in isoprene occurred too close to sunrise for the vegetation emitting isoprene to triple the concentrations of the previous hours. The increase of the total particle concentration could be due to new particle formation by photochemical reactions of precursor gases such as isoprene. Between 10:00 and 11:00 UTC particle concentrations decrease, likely due to dilution in an increasing mixing layer, until around 12:00 UTC, when the total particle concentration increases and is again dominated by nucleation events.

In the afternoon, starting around 14:00 UTC, $\mathrm{NO}_{\mathrm{x}}$ and $\mathrm{OH}$ reactivity increase again. The continuing low values of $\mathrm{SO}_{2}$ indicate that in air from this sector the influence of the local urban-industrial area is minimal.

After 17:00 UTC, a strong inversion layer rapidly developed; this was associated with an increase in the horizontal advection. From this time to midnight daily maxima of $\mathrm{NO}_{2}$, benzene and isoprene appeared. Isoprene emitted by biogenic sources located $70-80 \mathrm{~km}$ away from the sampling site in the early afternoon reaches the site $8 \mathrm{~h}$ later. The Natural Park of Sierra de Aracena is an important site of natural vegetation, with holm- and cork-oak trees, potential sources of terpenes, widely spread in this park. Therefore, the species of biogenic origin are likely emitted at distances of $70-80 \mathrm{~km}$, while anthropogenic species may have their origin at closer sources around $30 \mathrm{~km}$ away being accumulated in the nocturnal boundary layer.

$\mathrm{Fe}, \mathrm{Mn}$ and $\mathrm{Si}$ reached higher levels than in air from other sectors since these compounds are natural crustal elements from the ground. Similar levels were also measured in air from the Seville-Guadalquivir sector. On the other hand, this sector shows the absence of K, Na, As, Cd, Co, Sc, Se and $\mathrm{Zn}$.

\subsection{Seville-Guadalquivir sector}

The city of Seville is the most populated urban area in the south of Spain and air from the Seville-Guadalquivir sector is likely to carry emissions from Seville. Before arriving in Seville, the air masses are likely to move along the Guadalquivir valley. From Seville to El Arenosillo the air crosses the Doñana National Park. Accordingly, air from the
Seville-Guadalquivir sector has travelled through industrialurban and biogenic emissions sources.

These air masses present a clear continental influence, characterized by diurnal heating and nocturnal cooling, with the highest temperatures and thermal amplitudes observed during the campaign as well as the lowest values of humidity. Mixing layer heights in the afternoon reached $\sim 1500 \mathrm{~m}$. Despite development of stable nocturnal boundary layers for up to $12 \mathrm{~h}$, the differences observed in the potential temperature between 10 and $50 \mathrm{~m}$ were not high and similar to those observed in air from the Huelva-Portugal sector. The highest wind speed was recorded in air from this sector likely due to the channelling effect of the Guadalquivir valley. $\mathrm{OH}$ reactivity was highest during night-time, which could be attributed to the nocturnal atmospheric stability favouring horizontal advection, whereas unstable conditions inhibit the horizontal transport and have lower wind speeds.

$\mathrm{SO}_{2}$ shows low levels, and neither major nor trace particle components such as $\mathrm{K}, \mathrm{Na}, \mathrm{As}, \mathrm{Cd}, \mathrm{Co}, \mathrm{Sc}$ and $\mathrm{Se}$ were measured in air from this sector, thereupon Seville industrial-urban emissions of these substances did not reach El Arenosillo. In nocturnal stable conditions the values of $\mathrm{O}_{3}$, total particles concentration, benzene and isoprene did not change. An increase in the wind speed over the night, i.e. under suitable dispersion conditions, did not produce variations in these species.

In the early morning, around 09:00 to 11:00 UTC, the mixing processes started leading to increases in observed ozone, $\mathrm{NO}_{\mathrm{x}}$ and also isoprene. This increment could be mostly due to the vertical transport of aged emissions from the residual layer; $\mathrm{SO}_{2}$ and total particle concentration remained constant. In the afternoon, 14:00-16:00 UTC, with temperatures up to $16^{\circ} \mathrm{C}$ and a well established mixing layer, ozone and $\mathrm{NO}_{2}$ reach the daily maximum; isoprene follows an increasing trend. Taking into account the wind speed, the species measured at El Arenosillo at this time needed $8 \mathrm{~h}$ to travel from Seville, i.e. they would have been in the metropolitan area at around 06:00-08:00 UTC. Assuming that the photochemical activity started $\sim 10: 00$ UTC and using the wind speed recorded at this time, the isoprene emissions would have started $35 \mathrm{~km}$ away from El Arenosillo where coniferous forests are widely spread in the Doñana National Park in the direction of Seville. Ozone could be formed from $\mathrm{NO}_{\mathrm{x}}$ emitted in Seville; however, mixing ratios at El Arenosillo are not higher than in air from other sectors, thus secondary production of ozone in this season is not enhanced by Seville urban emissions. Around 17:00-18:00 UTC the ground starts to cool and the inversion layer begins to develop. Simultaneously an increase in the benzene, isoprene and total particle concentrations was observed, likely due to less dilution in the shallowing mixing layer.

Between 18:00 and 21:00 UTC the wind speed increased, while the difference of potential temperature showed the development of an intense inversion layer. Associated with the atmospheric stability, some chemical species may have 
accumulated in this air mass close to the ground during a longer time period, transporting pollutants from sources further away than Seville without mixing with higher air masses. The wind speed at this time was $\sim 3 \mathrm{~m} \mathrm{~s}^{-1}$, i.e. transport from Seville needed $7 \mathrm{~h}$ assuming a constant velocity. The peaks in $\mathrm{NO}_{\mathrm{x}}$ and ozone must be therefore due to a peak in $\mathrm{NO}_{\mathrm{x}}$ emissions in Seville in the early afternoon, which seems unlikely since the peak of urban $\mathrm{NO}_{\mathrm{x}}$ emissions is usually during rush hours in the morning and evening, or to sources closer to the site.

On the other hand, the lowest $\mathrm{PM}_{10}$ and $\mathrm{PM}_{10-2.5}$ concentrations are also found in air from this sector with $4.9 \mu \mathrm{g} \mathrm{m}^{-3}$ and $1.4 \mu \mathrm{g} \mathrm{m}^{-3}$, respectively. Even though only one filter is available for this sector, this result is further supported by the fact that total particle number (measured with a $10 \mathrm{~min}$ resolution) was also lowest for this sector (see Fig. 7), with the sole exception of marine air, for which higher amounts of large particles but low levels of small particles are to be expected. The main chemical compounds were $\mathrm{Fe}, \mathrm{Mn}$ and $\mathrm{Si}$, as was presented previously in the continental-north sector since they are natural crustal elements from the ground.

\subsection{Marine sector}

Air from the Atlantic sector is observed at the site with a high frequency throughout the year, and also occurred during the campaign. As was expected, the highest relative and specific humidity were encountered in air from this sector, as well as the lowest values for wind speed and the highest temperature, although the daily amplitude was minimal. The diurnal variability of the difference of potential temperatures showed values close to zero, i.e. neutral conditions, and the mixing layer height is the lowest, with $150-300 \mathrm{~m}$ in the afternoon, characteristic of a marine boundary layer. The trajectories calculated for $100 \mathrm{~m}$ altitude are close to the ocean surface without experiencing much vertical mixing.

Atlantic air masses transported little primary pollution, and the lowest levels of all the species analysed with the exception of ozone were observed in air from this sector. It is well know that ocean is not a source of $\mathrm{SO}_{2}$, benzene, isoprene or $\mathrm{NO}_{2}$; however, measurable concentrations of these species were found. These substances (except isoprene, which was below $5 \mathrm{ppt}$ ) are likely associated with maritime traffic with arriving and departing from the Huelva port. According to the emission inventory, an emission by ships of 243 and 330 ton $\mathrm{yr}^{-1}$ for $\mathrm{SO}_{2}$ and $\mathrm{NO}_{2}$ occurs.

Concentrations of trace components such as $\mathrm{S}, \mathrm{As}, \mathrm{Cu}, \mathrm{Ni}$, $\mathrm{Pb}$ and $\mathrm{Zn}$ are typical for marine air. And major sea salt components like $\mathrm{Na}$ are only observed within this sector while $\mathrm{K}$ reached its highest levels.

Under this atmospheric pattern the highest ozone mixing ratios of the campaign have been observed, between 35 to $40 \mathrm{ppb}$ throughout the day. There is no diurnal formation or nocturnal destruction; it is aged ozone with origin probably associated with long-range transport which has travelled over the ocean reaching the measurement area through the marine boundary layer. In order to follow the long-range transport under these conditions, back trajectories for the previous 10 days (data not shown) have been computed. The air had its origin in latitudes higher than $60^{\circ} \mathrm{N}$, moving over the North Atlantic from $\mathrm{N}$ to $\mathrm{S}$ between two low pressure systems located to the north and south of the British isles and a high pressure system located in the west at latitudes $<45^{\circ} \mathrm{N}$. Therefore, measurements from the marine sector typically reflect long-range transport of clean atmospheric background air.

\section{Conclusions}

The main goal of this work was to investigate the weather conditions, emission sources and land uses during the DOMINO campaign,in order to identify distinct air masses of different origins, and to analyse trace gases and particles in these air masses, in the southwest of the Iberian Peninsula during late autumn, when heat-driven turbulence and mixing of air masses are much less predominant than in summertime. The Mediterranean climate and a moderate solar radiation still allow a relatively high rate of photochemical activity compared to the rest of Europe. Coniferous and Mediterranean forests in the surroundings of the sampling site are not covered by snow. The site is also close to the Atlantic Ocean. Therefore, a range of primary and secondary species of diverse origins could be used for our study. Distinct air mass characteristics dependent on the origin of the air measured at El Arenosillo station were classified into four sectors of air mass origin with distinct emissions of anthropogenic urban and industrial as well as biogenic sources. The influence of boundary layer conditions under continental and marine influences was also taken into account in order to analyse the measured mixing ratios of primary and secondary gasphase pollutants and particles. Though the site is complex and many parameters interact with each other to influence the measured mixing ratios and concentrations, the use of land use maps together with back-trajectory calculations has permitted us to identify air masses with distinct chemistry and to discuss anthropogenic as well as biogenic emissions and their effect on the local composition of the air. Biogenic species in late autumn play a minor role in southern Spain, though they are still present in measurable concentrations. Long-range transport of anthropogenic as well as biogenic pollutants has measurable effects on local chemistry. This is especially evident for trace gases such as $\mathrm{SO}_{2}$, which varies from an average of $0.1-0.5 \mathrm{ppb}$ in air coming from the Seville-Guadalquivir valley, the marine and continental sectors to $2.5 \mathrm{ppb}$ in air passing the Huelva area; also for $\mathrm{NO}_{2}$ with a variation from $0.7 \mathrm{ppb}$ in air coming from the Marine, 1.6-1.8 ppb from the Seville-Guadalquivir and continental to the $2.3 \mathrm{ppb}$ in the air of the Huelva-Portugal 
sector. Particle composition even allows the identification of industrial sources at a distance of several tens of kilometres.

This study illustrates the importance of both chemistry and dynamics for the atmospheric composition of a rural site surrounded by sources of diverse nature, as are most rural sites. It is also meant to be a reference for all future studies with the data from the DOMINO campaign.

Acknowledgements. The authors would like to thank the Environmental Council of the Junta de Andalucía (Spain) for the emission inventory. We acknowledge NOAA Air Resources Laboratory for the provision of the HYSPLIT transport model. Our thanks to AEMET (the Spanish State Meteorological Agency) and European Centre for Medium-Range Weather Forecasts (ECMWF) for the access to the input meteorological fields used. Thanks to all the participants of the DOMINO campaign.

Edited by: A. Hofzumahaus

\section{References}

Adame, J. A., Bolívar, J. P., and De la Morena, B.: Surface ozone measurements in the Southwest of the Iberian Peninsula (Huelva, Spain). Environ. Sci. Pollut. R., 17, 355-368, doi:10.1007/s11356-008-0098-9, 2010a.

Adame, J. A., Serrano, E., Bolívar, J. P., and De la Morena, B.: On the tropospheric ozone variations in a coastal area of the southwestern Europe under mesoscale circulation, J. Appl. Meteorol. Clim., 49, 748-759, 2010b.

Antón, M., Sorribas, M., Bennouna, Y., Vilaplana, J. M., Cachorro, V. E., Gröbner, J., and Alados-Arboledas, L.: Effects of an extreme desert dust event on the spectral ultraviolet irradiance at El Arenosillo (Spain), J. Geophys. Res.-Atmos., 117, D03205, doi:10.1029/2011JD016645, 2012.

CMAJA: Inventario de Emisiones a la Atmósfera en Andalucía, http://www.juntadeandalucia.es/medioambiente (last access: March 2014), 2005.

Cristofanelli, P., Marinoni, A., Arduini, J., Bonafè, U., Calzolari, F., Colombo, T., Decesari, S., Duchi, R., Facchini, M. C., Fierli, F., Finessi, E., Maione, M., Chiari, M., Calzolai, G., Messina, P., Orlandi, E., Roccato, F., and Bonasoni, P.: Significant variations of trace gas composition and aerosol properties at Mt. Cimone during air mass transport from North Africa - contributions from wildfire emissions and mineral dust, Atmos. Chem. Phys., 9, 4603-4619, doi:10.5194/acp-9-4603-2009, 2009.

Crowley, J. N., Thieser, J., Tang, M. J., Schuster, G., Bozem, H., Beygi, Z. H., Fischer, H., Diesch, J.-M., Drewnick, F., Borrmann, S., Song, W., Yassaa, N., Williams, J., Pöhler, D., Platt, U., and Lelieveld, J.: Variable lifetimes and loss mechanisms for $\mathrm{NO}_{3}$ and $\mathrm{N}_{2} \mathrm{O}_{5}$ during the DOMINO campaign: contrasts between marine, urban and continental air, Atmos. Chem. Phys., 11, 10853-10870, doi:10.5194/acp-11-10853-2011, 2011.

De la Rosa, J. D., Sánchez de la Campa, A. M., Alastuey, A., Querol, X., González-Castanedo, Y., Fernández-Camacho, R., and Stein, A. F.: Using PM $_{10}$ geochemical maps for defining the origin of atmospheric pollution in Andalusia (Southern Spain), Atmos. Environ., 44, 4595-4605, 2010.
Diesch, J.-M., Drewnick, F., Zorn, S. R., von der WeidenReinmüller, S.-L., Martinez, M., and Borrmann, S.: Variability of aerosol, gaseous pollutants and meteorological characteristics associated with changes in air mass origin at the SW Atlantic coast of Iberia, Atmos. Chem. Phys., 12, 3761-3782, doi:10.5194/acp12-3761-2012, 2012.

Draxler, R. R. and Rolph, G. D.: HYSPLIT (HYbrid Single-Particle Lagrangian Integrated Trajectory) Model access via NOAA ARL READY Website, http://ready.arl.noaa.gov/HYSPLIT.php (last access: March 2014), NOAA Air Resources Laboratory, Silver Spring, MD, 2011.

Drewnick, F., Böttger, T., von der Weiden-Reinmüller, S.-L., Zorn, S. R., Klimach, T., Schneider, J., and Borrmann, S.: Design of a mobile aerosol research laboratory and data processing tools for effective stationary and mobile field measurements, Atmos. Meas. Tech., 5, 1443-1457, doi:10.5194/amt-5-1443-2012, 2012.

Frossard, A. A., Shaw, P. M., Russell, L. M., Kroll, J. H., Canagaratna, M. R., Worsnop, D. R., Quinn, P. K., and Bates, T. S.: Springtime Arctic haze contributions of submicron organic particles from European and Asian combustion sources, J. Geophys. Res., 116, D05205, doi:10.1029/2010JD015178, 2011.

Geyer, A., Bächmann, K., Hofzumahaus, A., Holland, F., Konrad, S., Klüpfel, T., Pätz, H., Perner, D., Mihelcic, D., Schäfer, H., Volz-Thomas, A., and Platt, U.: Nighttime formation of peroxy and hydroxyl radicals during the BERLIOZ campaign: Observations and modeling studies, J. Geophys. Res., 108, 8249, doi:10.1029/2001JD000656, 2003.

Gilge, S., Plass-Duelmer, C., Fricke, W., Kaiser, A., Ries, L., Buchmann, B., and Steinbacher, M.: Ozone, carbon monoxide and nitrogen oxides time series at four alpine GAW mountain stations in central Europe, Atmos. Chem. Phys., 10, 12295-12316, doi:10.5194/acp-10-12295-2010, 2010.

Grahame, T. and Hidy, G.: Using factor analysis to attribute health impacts to particulate pollution sources, Inhal. Toxicol., 16, 143$152,2004$.

Hernández-Ceballos, M. A., Adame, J. A., Bolívar, J. P., and De la Morena, B. A.: Vertical behaviour and meteorological properties of air masses in the southwest of the Iberian Peninsula (1997-2007), Meteorol. Atmos. Phys., 119, 163-175, doi:10.1007/s00703-012-0225-5, 2013.

Hosaynali Beygi, Z., Fischer, H., Harder, H. D., Martinez, M., Sander, R., Williams, J., Brookes, D. M., Monks, P. S., and Lelieveld, J.: Oxidation photochemistry in the Southern Atlantic boundary layer: unexpected deviations of photochemical steady state, Atmos. Chem. Phys., 11, 8497-8513, doi:10.5194/acp-118497-2011, 2011.

INE: Instituto Nacional de Estadística: Censo de 2008, http://www. ine.es/ (last access: March 2014), 2009.

Kothai, P., Saradhi, I. V., Pandit, G. G., Markwitz, A., and Puranik, V. D.: Chemical characterization and source identification of particulate matter at an urban site of Navi Mumbai, India. Aerosol and Air Quality Research, 11, 560-569, 2011.

Martinez, M., Harder, H., Kubistin, D., Rudolf, M., Bozem, H., Eerdekens, G., Fischer, H., Klüpfel, T., Gurk, C., Königstedt, R., Parchatka, U., Schiller, C. L., Stickler, A., Williams, J., and Lelieveld, J.: Hydroxyl radicals in the tropical troposphere over the Suriname rainforest: airborne measurements, Atmos. Chem. Phys., 10, 3759-3773, doi:10.5194/acp-10-3759-2010, 2010. 
Molina, L. T., Madronich, S., Gaffney, J. S., Apel, E., de Foy, B., Fast, J., Ferrare, R., Herndon, S., Jimenez, J. L., Lamb, B., Osornio-Vargas, A. R., Russell, P., Schauer, J. J., Stevens, P. S., Volkamer, R., and Zavala, M.: An overview of the MILAGRO 2006 Campaign: Mexico City emissions and their transport and transformation, Atmos. Chem. Phys., 10, 8697-8760, doi:10.5194/acp-10-8697-2010, 2010.

Notario, A., Bravo, I., Adame, J. A., Díaz-de-Mera, Y., Aranda, A., Rodríguez, A., and Rodríguez, D.: Partitioning, sources and variability of regional and local oxidant $\left(\mathrm{OX}=\mathrm{O}_{3}+\mathrm{NO}_{2}\right)$ in a coastal rural area in the southwest of Iberian Peninsula, Environ. Sci. Pollut. R., 20, 6059-6069, doi:10.1007/s11356-013-1642-9, 2013.

Parrish, D. D., Law, K. S., Staehelin, J., Derwent, R., Cooper, O. R., Tanimoto, H., Volz-Thomas, A., Gilge, S., Scheel, H.-E., Steinbacher, M., and Chan, E.: Lower tropospheric ozone at northern midlatitudes: Changing seasonal cycle, Geophys. Res. Lett., 40, 1631-1636, doi:10.1002/grl.50303, 2013.

Querol, X., Alastuey, A., De la Rosa, J., Sánchez de la Campa, A., Plana, F., and Felicià Ruiz, C. R.: Source apportionment analysis of atmospheric particulates in an industrialised urban site in Southwestern Spain, Atmos. Environ., 36, 3113-3125, 2002.

Querol, X., Alastuey, A., Moreno, T., Viana, M. M., Castillo, S., Pey, J., Rodríguez, S., Artiñano, B., Salvador, P., Sánchez, M., Garcia Dos Santos, S., Herce Garraleta, M. D., Fernández-Patier, R., Moreno-Grau, S., Negral, L., Minguillón, M. C., Monfort, E., Sanz, M. J., Palomo-Marín, R., Pinilla-Gil, E., Cuevas, E., De la Rosa, J., and Sánchez de la Campa, A.: Spatial and temporal variations in airborne particulate matter $\left(\mathrm{PM}_{10}\right.$ and $\left.\mathrm{PM}_{2.5}\right)$ across Spain 1995-2005, Atmos. Environ., 42, 3964-3979, 2008.

Royer, P., Chazette, P., Sartelet, K., Zhang, Q. J., Beekmann, M., and Raut, J.-C.: Comparison of lidar-derived $\mathrm{PM}_{10}$ with regional modeling and ground-based observations in the frame of MEGAPOLI experiment, Atmos. Chem. Phys., 11, 1070510726, doi:10.5194/acp-11-10705-2011, 2011.

Sánchez de la Campa, A. M., Pio, C., De la Rosa, J., Querol, X., Alastuey, A., and González-Castanedo, Y.: Characterization and origin of EC and OC particulate matter near the Doñana National Park (SW Spain), Environ. Res., 109, 671-681, 2009.

Seibert, P., Beyrich, F., and Gryning, S.: Review and intercomparison of operational methods for the determination of the mixing height, Atmos. Environ., 34, 1001-1027, 2000.

Sinha, V., Williams, J., Crowley, J. N., and Lelieveld, J.: The Comparative Reactivity Method - a new tool to measure total $\mathrm{OH}$ Reactivity in ambient air, Atmos. Chem. Phys., 8, 2213-2227, doi:10.5194/acp-8-2213-2008, 2008.

Sinha, V., Custer, T. G., Kluepfel, T., and Williams, J.: The effect of relative humidity on the detection of pyrrole by PTR-MS for OH reactivity measurements, Int. J. Mass Spectrom., 282, 108-111, 2009.

Sinha, V., Williams, J., Lelieveld, J., Ruuskanen, T. M., Kajos, M. K., Patokoski, J., Hellen, H., Hakola, H., Mogensen, D., Boy, M., Rinne, J., and Kulmala, M.: OH Reactivity Measurements within a Boreal Forest: Evidence for Unknown Reactive Emissions, Environ. Sci. Technol., 44, 6614-6620, 2010.

Sinha, V., Williams, J., Diesch, J. M., Drewnick, F., Martinez, M., Harder, H., Regelin, E., Kubistin, D., Bozem, H., HosaynaliBeygi, Z., Fischer, H., Andrés-Hernández, M. D., Kartal, D., Adame, J. A., and Lelieveld, J.: Constraints on instantaneous ozone production rates and regimes during DOMINO derived using in-situ $\mathrm{OH}$ reactivity measurements, Atmos. Chem. Phys., 12, 7269-7283, doi:10.5194/acp-12-7269-2012, 2012.

Song, W., Williams, J., Yassaa, N., Martinez, M., Adame, J. A., Hidalgo, P. J., Bozem, H., and Lelieveld, J.: Winter and summer characterization of biogenic enantiomeric monoterpenes and anthropogenic BTEX compounds at a Mediterranean Stone Pine forest site, J. Atmos. Chem., 68, 233-250, 2011.

Sörgel, M., Regelin, E., Bozem, H., Diesch, J.-M., Drewnick, F., Fischer, H., Harder, H., Held, A., Hosaynali-Beygi, Z., Martinez, M., and Zetzsch, C.: Quantification of the unknown HONO daytime source and its relation to $\mathrm{NO}_{2}$, Atmos. Chem. Phys., 11, 10433-10447, doi:10.5194/acp-11-10433-2011, 2011.

Sorribas, M., de la Morena, B. A., Wehner, B., López, J. F., Prats, N., Mogo, S., Wiedensohler, A., and Cachorro, V. E.: On the sub-micron aerosol size distribution in a coastal-rural site at El Arenosillo Station (SW - Spain), Atmos. Chem. Phys., 11, 11185-11206, doi:10.5194/acp-11-11185-2011, 2011.

Toledano, C., Cachorro, V. E., Berjon, A., de Frutos, A. M., Sorribas, M., De la Morena, B. A., and Goloub, P.: Aerosol optical depth and Angström exponent climatology at El Arenosillo AERONET site (Huelva, Spain), Q. J. Roy. Meteor. Soc., 133, 795-807, 2007.

van Stratum, B. J. H., Vilà-Guerau de Arellano, J., Ouwersloot, H. G., van den Dries, K., van Laar, T. W., Martinez, M., Lelieveld, J., Diesch, J.-M., Drewnick, F., Fischer, H., Hosaynali Beygi, Z., Harder, H., Regelin, E., Sinha, V., Adame, J. A., Sörgel, M., Sander, R., Bozem, H., Song, W., Williams, J., and Yassaa, N.: Case study of the diurnal variability of chemically active species with respect to boundary layer dynamics during DOMINO, Atmos. Chem. Phys., 12, 5329-5341, doi:10.5194/acp-12-53292012, 2012.

Williams, J., Crowley, J., Fischer, H., Harder, H., Martinez, M., Petäjä, T., Rinne, J., Bäck, J., Boy, M., Dal Maso, M., Hakala, J., Kajos, M., Keronen, P., Rantala, P., Aalto, J., Aaltonen, H., Paatero, J., Vesala, T., Hakola, H., Levula, J., Pohja, T., Herrmann, F., Auld, J., Mesarchaki, E., Song, W., Yassaa, N., Nölscher, A., Johnson, A. M., Custer, T., Sinha, V., Thieser, J., Pouvesle, N., Taraborrelli, D., Tang, M. J., Bozem, H., Hosaynali-Beygi, Z., Axinte, R., Oswald, R., Novelli, A., Kubistin, D., Hens, K., Javed, U., Trawny, K., Breitenberger, C., Hidalgo, P. J., Ebben, C. J., Geiger, F. M., Corrigan, A. L., Russell, L. M., Ouwersloot, H. G., Vilà-Guerau de Arellano, J., Ganzeveld, L., Vogel, A., Beck, M., Bayerle, A., Kampf, C. J., Bertelmann, M., Köllner, F., Hoffmann, T., Valverde, J., González, D., Riekkola, M.-L., Kulmala, M., and Lelieveld, J.: The summertime Boreal forest field measurement intensive (HUMPPA-COPEC-2010): an overview of meteorological and chemical influences, Atmos. Chem. Phys., 11, 10599-10618, doi:10.5194/acp-11-10599-2011, 2011. 